Australian

National

University

Crawford School of Public Policy

\title{
CAMA
}

Centre for Applied Macroeconomic Analysis

\section{Global macroeconomic cooperation in response to the COVID-19 pandemic: a roadmap for the $\mathbf{G} 20$ and the IMF}

\section{CAMA Working Paper 68/2020 July 2020}

\section{Warwick McKibbin}

Centre for Applied Macroeconomic Analysis, ANU

Centre of Excellence in Population Ageing Research, ANU

The Brookings Institution

\section{David Vines}

Department of Economics, Balliol College, University of Oxford Institute for New Economic Thinking (INET), University of Oxford CEPR

Centre for Applied Macroeconomic Analysis, ANU 


\section{Abstract}

The COVID-19 crisis has caused the greatest collapse in global economic activity since 1720. Some advanced countries have mounted a massive fiscal response, both to pay for disease-fighting action and to preserve the incomes of firms and workers until the economic recovery is under way. But there are many emerging market economies which have been prevented from doing what is needed by their high existing levels of public debt and-especially-by the external financial constraints which they face. We argue in the present paper that there is a need for international cooperation to allow such countries to undertake the kind of massive fiscal response that all countries now need, and that many advanced countries have been able to carry out. We show what such cooperation would involve. We use a global macroeconomic model to explore how extraordinarily beneficial such cooperation would be. Simulations of the model suggest that GDP in the countries in which extra fiscal support takes place would be around two and a half per cent higher in the first year, and that GDP in other countries in the world be more than one per cent higher. So far, such cooperation has been notably lacking, in striking contrast with what happened in the wake of the Global Financial Crisis in 2008. The necessary cooperation needs to be led by the Group of Twenty (G20), just as happened in 2008-9, since the G20 brings together the leaders of the world's largest economies. This cooperation must also necessarily involve a promise of international financial support from the International Monetary Fund, otherwise international financial markets might take fright at the large budget deficits and current account deficits which will emerge, creating fiscal crises and currency crises and so causing such expansionary policies which we advocate to be brought to an end.

\section{Keywords}

COVID-19, risk, macroeconomics, DSGE, CGE, G-Cubed (G20)

\section{JEL Classification}

C54, C68, E27, E61, E62, F41, F 42, 055

\section{Address for correspondence:}

(E) cama.admin@anu.edu.au

\section{ISSN 2206-0332}

The Centre for Applied Macroeconomic Analysis in the Crawford School of Public Policy has been established to build strong links between professional macroeconomists. It provides a forum for quality macroeconomic research and discussion of policy issues between academia, government and the private sector.

The Crawford School of Public Policy is the Australian National University's public policy school, serving and influencing Australia, Asia and the Pacific through advanced policy research, graduate and executive education, and policy impact. 


\title{
Global macroeconomic cooperation in response to the COVID-19 pandemic: a roadmap for the $\mathrm{G20}$ and the IMF
}

\author{
Warwick McKibbin* and David Vines**
}

\begin{abstract}
The COVID-19 crisis has caused the greatest collapse in global economic activity since 1720. Some advanced countries have mounted a massive fiscal response, both to pay for disease-fighting action and to preserve the incomes of firms and workers until the economic recovery is under way. But there are many emerging market economies which have been prevented from doing what is needed by their high existing levels of public debt and - especially - by the external financial constraints which they face. We argue in the present paper that there is a need for international cooperation to allow such countries to undertake the kind of massive fiscal response that all countries now need, and that many advanced countries have been able to carry out. We show what such cooperation would involve. We use a global macroeconomic model to explore how extraordinarily beneficial such cooperation would be. Simulations of the model suggest that GDP in the countries in which extra fiscal support takes place would be around two and a half per cent higher in the first year, and that GDP in other countries in the world be more than one per cent higher. So far, such cooperation has been notably lacking, in striking contrast with what happened in the wake of the Global Financial Crisis in 2008. The necessary cooperation needs to be led by the Group of Twenty (G20), just as happened in 2008-9, since the G20 brings together the leaders of the world's largest economies. This cooperation must also necessarily involve a promise of international financial support from the International Monetary Fund, otherwise international financial markets might take fright at the large budget deficits and current account deficits which will emerge, creating fiscal crises and currency crises and so causing such expansionary policies which we advocate to be brought to an end.
\end{abstract}

Keywords: COVID-19, risk, macroeconomics, DSGE, CGE, G-Cubed (G20)

JEL classification: C54, C68, E27, E61, E62, F41, F 42, 055

* Centre for Applied Macroeconomic Analysis, and Centre of Excellence in Population Ageing Research, Crawford School of Public Policy, Australian National University, and The Brookings Institution, Washington DC; e-mail: warwick.mckibbin@anu.edu.au

** Department of Economics, Balliol College, and Institute for New Economic Thinking (INET), University of Oxford; and CEPR; e-mail: david.vines@economics.ox.ac.uk

We gratefully acknowledge financial support from the Australia Research Council Centre of Excellence in Population Ageing Research (CE170100005). We thank Peter Wilcoxen for his substantial and ongoing contributions to the modelling research on which this paper is built, Larry Liu for his support with data and advice and helpful comments on a draft of this paper, and especially Roshen Fernando for his contribution to the framework set out in McKibbin and Fernando $(2020 a, b)$. We thank Chris Adam and Simon Wren-Lewis for helpful comments on an earlier draft of his paper. And we are grateful to many people for helpful discussions, over a number of years, of the ideas raised in this paper, including in particular Christopher Allsopp, Shiro Armstrong, Olivier Blanchard, Tam Bayoumi, Max Corden, Peter Drysdale, Renee Fry-McKibbin, David Gruen, Vijay Joshi, Paul Krugman, Martin Parkinson, Barry Sterland, and Paola Subacchi. 


\section{Introduction and summary}

The COVID-19 crisis has caused the greatest collapse in global economic activity since the collapse of the South Sea Bubble in 1720; much larger than what happened during the Global Financial Crisis (GFC) of 2008 or the Great Depression in the 1930s. ${ }^{1}$ Some advanced countries-e.g. the US, Germany, Japan, and Australia-have mounted a massive fiscal response, both to pay for diseasefighting action and to preserve the incomes of firms and workers until the economic recovery is under way. But going beyond the Group of Ten (G10) there are many emerging market economies - Brazil, South Africa, Argentina, India, Indonesia - which are being prevented from doing what is needed by their high existing levels of public debt and — especially — by the external financial constraints which they face. ${ }^{2}$

We argue in the present paper that there is a need for international cooperation to allow such countries to undertake the kind of massive fiscal response that all countries now need, and that many advanced countries have been able to carry out. We argue that such cooperation would need to involve very large sums of money. We use a global macroeconomic model to explore how extraordinarily beneficial such cooperation might be. Simulations of the model suggest that GDP in the countries in which extra fiscal support takes place would be something like two and a half per cent higher in the first year, and that GDP in other countries in the world be more than one per cent higher. And the percentage increase in employment in the countries in which there is extra fiscal support would be very much larger than the percentage increase in GDP.

So far, such cooperation has been notably lacking (Lee, 2020).

The contrast with what happened in the wake of the GFC is very striking. That crisis hit the world on Sunday 15 September 2008, the day on which Lehman Brothers was allowed to collapse. Massive unilateral fiscal responses to that crisis began on the next day when the US Federal Reserve and the US Treasury together saved the massive insurance giant AIG from collapsing. Within weeks the British government had injected tens of billions of dollars to save the Royal Bank of Scotland and the Bank of Scotland. But by November the first international moves towards cooperation began at a G20 Summit in Washington at which world leaders agreed not to raise taxes to cover the fiscal deficits which were emerging as economies imploded and tax revenues collapsed. Crucially this was followed by a further G20 Summit in London in April 2008 at which Gordon Brown and Barak Obama, then Prime Minister of the UK and President of the USA, respectively, coordinated significant global action. World leaders agreed to a massive fiscal injection equal to nearly 2 per cent of world GDP, something unheard of at the time. What was agreed proved particularly helpful for emerging-market economies, and developing countries, in that it included massive infrastructure investment in China, something which helped to sustain the prices of primary commodities and of energy.

By contrast, the meeting of G20 finance ministers and central bank governors which took place on 15 April 2020 achieved nothing of this kind. It is true that the meeting agreed a 1-year freeze of bilateral government (and private sector, on a voluntary basis) loan repayments for low-income countries. There was agreement to make \$200 billion available through Multilateral Development Banks and to deploy

\footnotetext{
${ }^{1}$ See Temin and Voth (2004), Broadberry and van Leeuwen (2010), Rei (2020).

${ }^{2}$ This problem is also present for countries in sub-Saharan Africa. We do not discuss such countries in this paper but they are discussed in detail in the paper by Adam et al. (2020, this issue).
} 
the International Monetary Fund's resources in an accelerated manner. However, the leaders failed to agree on a new allocation of special drawing rights (SDRs). And there was no agreement about any concerted fiscal action of the kind which happened in London in April 2008 (Bery and Brekelmans, 2020).

The present paper provides a roadmap for at least part of the international cooperation that is now needed. The size of the additional fiscal support which we are recommending is huge, a total of nearly $\$ 2$ trillion. This comes on top of the vast amount that has already been spent, or promised, by advanced countries. The total of such expenditure and promises is about $\$ 9$ trillion. World GDP is somewhere between $\$ 80$ trillion and $\$ 100$ trillion, depending on how it is measured, so what has already been spent or promised amounts to about 10 per cent of World GDP, a staggering sum. We are calling for a total of $\$ 2$ trillion to be added to this, to enable those countries who have not yet been able to do what is necessary to begin to be able to do so.

This cooperation needs to be led by the Group of Twenty, or G20, just as happened in 2008-9. The G20 brings together the leaders of the world's largest economies. An agreement by the leaders of these countries that such fiscal support is what is necessary would give it the same kind of legitimacy which was achieved at the G20 meeting in London in April 2009. This legitimacy has so far has been denied to governments in the face of the present crisis, precisely because they have needed to act on their own. Only some countries in the G10 have been able to do what is necessary.

Such cooperation must also necessarily involve the International Monetary Fund (IMF) providing a promise of international financial support, since otherwise international portfolio managers might well take fright at the large fiscal and current account deficits which will emerge, creating currency crises and so causing such expansionary policies to be brought to an end. Of course, with this international confidence-building sanction which such support would provide, private financial markets might well lend what such countries need, meaning that ex post the IMF may need to provide very little financial support.

In this paper we use a global macroeconomic model to show, in detail, just what such cooperation would need to involve. To do this we will use the G-Cubed (G20) model, a version of the model which has been developed by Warwick McKibbin and Peter Wilcoxen since 1991. We are able to use model to explore how extraordinarily beneficial such cooperation might be.

The paper is organized as follows. In section II we summarize the parlous state of the world economy as at June 2020 and the likely path over the next few years as outlined in a scenario from McKibbin and Fernando (2020b). We also show the fiscal responses that have been implemented to date. Section III outlines the role of the G20 in the global financial crisis a decade ago and argues that the important lessons from that period of global cooperation should be applied to the current crisis. Section IV lays out the analytical framework for thinking about the problem of policy coordination and clarifying the key insights from a large literature that can be applied to the current response to the COVID-19 crisis. We focus on two aspects of the likely gains from coordination. One is the possibility to implement fiscal support in currently constrained economies, and the second is the implication for global risk that could come from averting an even greater economic crisis due to concerted and coordinated macroeconomic policy response. The G-Cubed (G20) model that forms the basis of the empirical analysis is set out in section V. Section VI outlines the way the shocks are designed in the global 
scenario on which we base our analysis and summarizes the policy simulations and risk shocks that capture a coordinated policy response. Section VII presents results from the implementation of the coordinated fiscal policy response. A summary and conclusion are contained in section VIII.

\section{The state of the world economy in June 2020 \\ (i) The enormous size of the problem}

In order to explore the impacts of G20 cooperation we need an estimate of the current state of the world economy and its likely future path. There have been several recent estimates of the sharp decline in global economic activity as of June 2020 by the IMF (2020a, b), World Bank (2020), OECD (2020), and McKibbin and Fernando (2020b). There is enormous uncertainty in the future course of the COVID-19 pandemic and the economic implications. Thus, each of the studies explores a range of scenarios to give some idea of the wide-ranging possibilities for the next few years. We choose one of the scenarios from McKibbin and Fernando (2020b) because we are using the same model as is used in that study. The scenario is called Scenario 05 in that study. In our paper we call it the Baseline Scenario. While it is not the most severe scenario, it has several characteristics that are of interest in evaluating how G20 policy cooperation might benefit the global economy.

In our Baseline Scenario (the fifth scenario in McKibbin and Fernando, 2020b) it is assumed that the first wave of the pandemic has the impact observed as of 20 May with additional infections and deaths following an estimated logistics curve for countries that still have rising infections by that date. Thus, for some countries, like Australia, the number of infections has stabilized, whereas for Brazil the number of infections was still rising rapidly on 20 May. Based on similar countries, the authors estimate when infections are likely to stabilize in Brazil, under the assumption that there is no vaccine developed. A key assumption in this scenario is that the pandemic continues to emerge in subsequent years. The countries that followed lockdown discard that policy in future outbreaks after the first wave. This means that without lockdowns the number of infections in all future waves surges compared to the first wave, in all countries, until there is herd immunity. As a result, the number of deaths in 2021 is much larger than in 2020. Once there is herd immunity, the pandemic eventually dies out. In this scenario, we assume that the increase in the equity risk premia caused by the pandemic does not return to baseline so that there is a permanent change in global risk.

The baseline epidemiological assumptions and the implications for the global economy relative to the non-COVID-19 projections for 2020 and 2021 are summarized in Table 1. This shows the number of infections, the number of deaths, the loss in GDP relative to the no-pandemic baseline, and the cumulative loss in GDP from 2020 to 2025 in \$US. 
Table 1: Infections, deaths, and GDP loss due to the pandemic in the baseline

\begin{tabular}{|c|c|c|c|c|c|c|}
\hline \multirow[b]{2}{*}{ Country/Region } & \multicolumn{2}{|c|}{ Infections } & \multicolumn{2}{|c|}{ Deaths } & \multicolumn{2}{|r|}{ GDP Loss } \\
\hline & 2020 & 2021 & 2020 & 2021 & $\begin{array}{c}2020 \\
\%\end{array}$ & $\begin{array}{c}\text { Cumulative 2020-2025 } \\
\text { SUS billion }\end{array}$ \\
\hline Argentina & 45,392 & 64,845 & 2,075 & 2,964 & -13.54 & -217.77 \\
\hline Australia & 25,890 & 36,985 & 363 & 519 & -10.79 & -306.63 \\
\hline Brazil & $2,142,888$ & $3,061,268$ & 141,544 & 202,206 & -17.85 & $-1,271.31$ \\
\hline Canada & 297,533 & 425,048 & 22,267 & 31,810 & -9.40 & -397.54 \\
\hline China & 294,218 & 420,312 & 16,233 & 23,190 & -7.86 & $-4,924.32$ \\
\hline France & 502,354 & 717,648 & 99,270 & 141,814 & -12.25 & -785.72 \\
\hline Germany & 615,114 & 878,734 & 28,110 & 40,158 & -11.30 & -989.42 \\
\hline India & 665,311 & 950,444 & 20,807 & 29,724 & -9.55 & $-2,914.95$ \\
\hline Indonesia & 77,041 & 110,059 & 5,095 & 7,278 & -7.38 & -650.71 \\
\hline Italy & 797,218 & $1,138,884$ & 112,962 & 161,375 & -14.20 & -830.45 \\
\hline Japan & 57,983 & 82,833 & 2,703 & 3,862 & -13.76 & $-1,561.81$ \\
\hline Mexico & 297,866 & 425,523 & 30,760 & 43,943 & -6.62 & -573.36 \\
\hline Other Asia & 212,084 & 302,978 & 4,213 & 6,019 & -11.65 & -690.66 \\
\hline Other oil producing countries & $1,171,676$ & $1,673,823$ & 49,992 & 71,416 & -8.81 & $-1,046.04$ \\
\hline Republic of Korea & 38,777 & 55,396 & 921 & 1,315 & -6.27 & -280.84 \\
\hline Rest of Euro Zone & $1,825,036$ & $2,607,194$ & 190,790 & 272,557 & -14.84 & -339.61 \\
\hline Rest of OECD & 381,477 & 544,968 & 9,555 & 13,650 & -11.42 & -585.80 \\
\hline Rest of the World & $2,060,914$ & $2,944,163$ & 53,071 & 75,815 & -10.81 & -777.83 \\
\hline Russia & $1,330,384$ & $1,900,549$ & 12,458 & 17,797 & -15.49 & $-6,968.17$ \\
\hline Saudi Arabia & 296,197 & 423,138 & 1,653 & 2,361 & -5.26 & -845.95 \\
\hline South Africa & $2,441,462$ & $3,487,803$ & 42,491 & 60,702 & -26.36 & $-3,678.91$ \\
\hline Turkey & 534,998 & 764,283 & 14,818 & 21,168 & -8.13 & -687.51 \\
\hline United Kingdom & 912,715 & $1,303,878$ & 128,888 & 184,126 & -7.95 & -381.39 \\
\hline United States of America & $5,605,823$ & $8,008,318$ & 335,744 & 479,634 & -14.75 & $-3,653.80$ \\
\hline Total & $22,630,352$ & $32,329,074$ & $1,326,783$ & $1,895,404$ & & $-35,360.49$ \\
\hline
\end{tabular}

Source: McKibbin and Fernando, 2020b, Tables 5, 6, 11, and 12.

Clearly the economic contraction is enormous with GDP in 2020 declining by close to 10 per cent relative to the no-COVID projections for 2020. This translates into a decline in world economic growth from 2019 to 2020 of around 6.5 per cent. The cumulative global GDP loss from 2020 to 2025 is a massive \$US35 trillion. The GDP loss is distributed very unevenly across countries. This partly reflects the nature of the pandemic but also importantly the policy responses as at June 2020 .

\section{(ii) The fiscal policy response as at June 2020}

Governments have put forward swift and significant emergency lifelines to protect people in response to the pandemic. The IMF measured these in the April 2020 Fiscal Monitor and, as countries have stepped up their efforts, the IMF has updated its numbers. 
Figure 1: G20 fiscal response to the COVID-19 pandemic

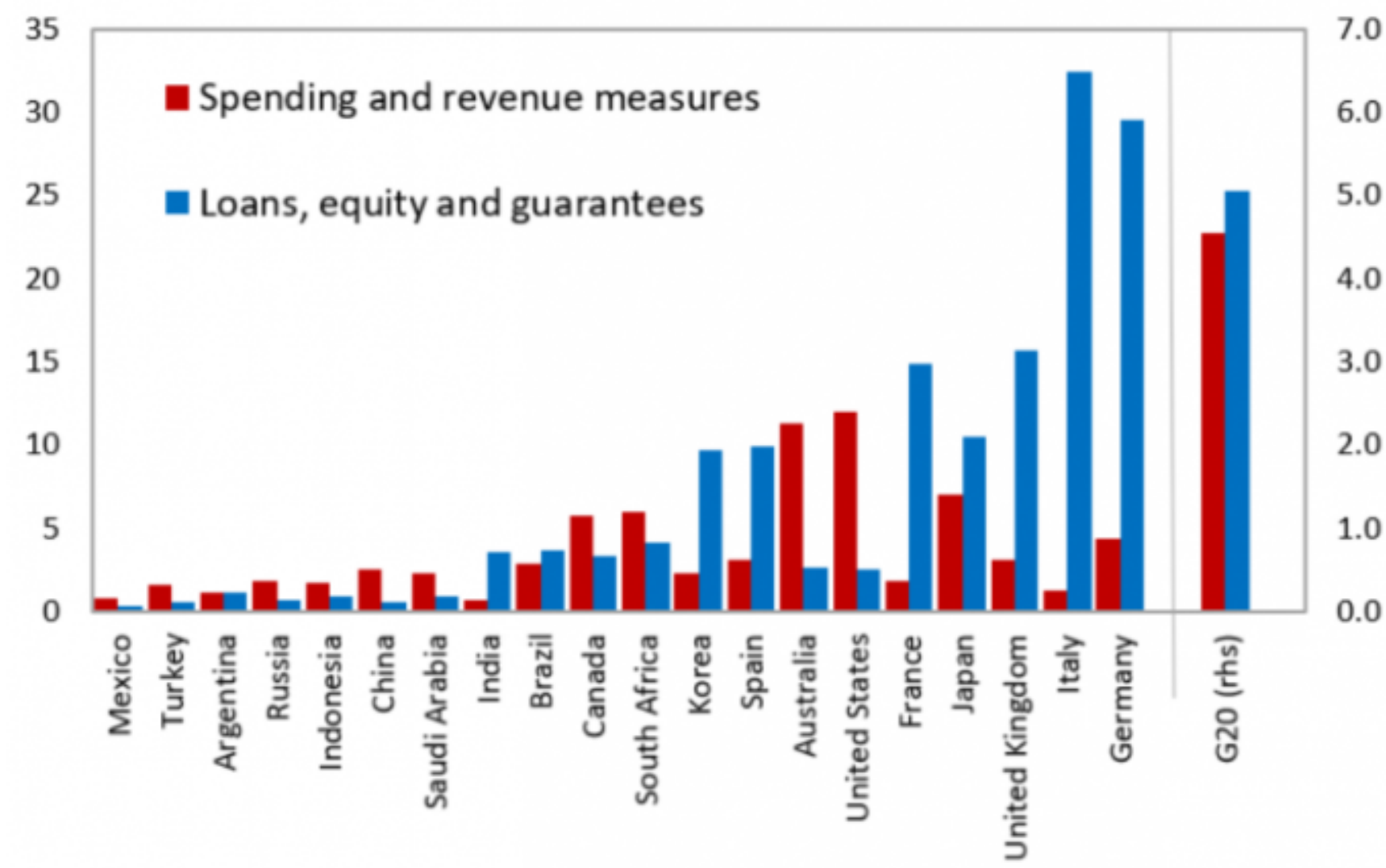

\section{Announced fiscal measures in G20 economies, \% of GDP}

Note: $\mathrm{G} 20$ = Group of twenty. G20 aggregates are calculated using PPP-adjusted GDP weights. Estimates focus on government discretionary measures that supplement existing automatic stabilizers, which differ across countries in their breadth and scope.

Source: IMF, 2020c.

The total by June 2020 is about $\$ 9$ trillion. The composition is: direct budget support is currently estimated at $\$ 4.4$ trillion globally, and additional public-sector loans and equity injections, guarantees, and other quasi-fiscal operations (such as non-commercial activity of public corporations) amount to another $\$ 4.6$ trillion.

The G20 advanced and emerging market economies account for the bulk of the global fiscal support$\$ 8$ trillion. The total revenue and spending measures for G20 countries account for 4.5 per cent of GDP on average, much larger than what happened during the global financial crisis. ${ }^{3}$

\footnotetext{
3 As IMF (2020c) makes clear, the fiscal measures take various forms and have different budgetary and debt-related implications. The IMF estimates focus on discretionary revenue and spending measures but exclude deferral of taxes and social security contributions to the extent possible. The IMF excludes these because they involve a temporary delay of revenue, which will be collected in the future (sometimes within the same fiscal year). The estimates also classify separately
} 


\section{The role of the $\mathbf{G 2 0}$ in leading international cooperation}

The global financial crisis which struck in 2008-9 provides evidence of how the cooperation which we advocate could be put in place. At the time of that earlier crisis, there were two aspects to this cooperation.

The first aspect involved a recognition of the crucial role of fiscal policy. Keynes was back, after a period of nearly 20 years, including the Great Moderation of the early 2000s, in which economies had been managed by monetary policy. In that period there had been little international cooperation in the conduct of macroeconomic policy. Macroeconomic policy focused on inflation targeting and the use of monetary policy in the pursuit of this objective. When the zero bound was reached in the face of a massive economic downturn, fiscal policy was back in play (Allsopp and Vines, 2015).

The second feature was the institutionalization of international cooperation, something which was made possible by turning the G20 (which had been simply a forum in which meetings of finance ministers were held) into a Leaders Summit, preceded by considerable preparatory work carried out by national Sherpas. The leadership of Gordon Brown, who was supported by a highly effective team of UK civil servants, was crucial in putting such effective leadership in place. The London summit, chaired by Brown, agreed on the huge fiscal support which we have already described. This was crucial in laying the foundations for the global recovery which followed.

But in the next few years the G20 rapidly lost its head of steam, for two reasons.

First, fiscal expansion was abandoned as an objective of policy, in pursuit of austerity. This push was led by Wolfgang Schauble from Germany, guided by his belief in the importance of macroeconomic discipline. In the UK George Osborne embraced an 'obligation' to get debt down by cutting public expenditure, especially on welfare benefits, in ways which the COVID-19 crisis has shown to have been disastrous. In the US, Barak Obama and Larry Summers's room to move was utterly hemmed in by a Republican determination to wreck the legacy of Obama's Presidency.

Second a lack of leadership led to a lack of focus. By 2013, when Russia chaired the G20, the Leaders' Declaration became a wish-list full of all sorts of things with no clear mechanism in place for delivery.

Nevertheless, when Australia became G20 Chair in 2014, Australian officials were determined both to re-establish a focus on improved macroeconomic policy-making and to impose a mechanism of delivery. This led to the '2-in-5' agreement at the Heads of Government meeting in Brisbane in November 2014: a list of policies to which global leaders were committed, designed to increase global growth by 2 per cent over a period of 5 years. Subsequent reviews judged this policy agreement to have been at least partially successful in influencing global macroeconomic outcomes. But subsequently, up until 2016, the G20 gradually returned to drift and irrelevance; very little was achieved in 2015 when Turkey held the G20 Chair or, indeed, in 2016 when China was in the Chair. After the election of President Trump in the US in 2016, the US turned to a policy of deliberate obstruction.

governments' provision of loans and equity injection that have an immediate effect on the government balance sheet, along with guarantees that expose the government to risks if the guarantees were called in after some time. 


\section{Concerted unilateralism: a particular form of international cooperation?}

Why was the G20 able to be effective, both in 2008-9 and - less obviously - in 2014? How - in the case of the current crisis - might the G20 resume a place of global importance? Australian scholars and officials have put forward a framework of analysis which might help in answering these two questions.

These scholars have used the term 'concerted unilateralism' to describe the form of international cooperation which the G20 has, at its best, adopted and then carried out (Garnaut, 1996; Vines 2016). As a preliminary process, leaders are asked to agree on focus - to agree about what it is that countries are trying to achieve. In 2014, when Australia chaired the G20, the objective was to raise the global growth rate. First, countries were all invited to propose policies which each might embark upon on, so as to contribute to this overall global objective. Second, each country's proposals would be reviewed by another country to see if what had been proposed was 'fair' in the sense of making an adequate contribution to the overall objective. If necessary (and this happened in 2014) countries would then be invited to 'do a bit more', so that the whole thing added up to enough. What was essential—said the Australian officials - was that there was not a process of top-down instruction, and top-down enforcement of conditionality. ${ }^{4}$ It is interesting that the successful Paris climate conference of 2016 adopted such an approach after the disastrous outcome at the Copenhagen conference which had tried and failed to adopt a top-down method of policy implementation.

In what follows we discuss what such concerted unilateralism might make possible. In the conclusion to the paper we discuss how the process of international cooperation might actually be managed.

\section{The nature of international cooperation that is needed}

\section{(i) Background}

It is well known (see Currie and Levine (1985), Eichengreen (1985), Oudiz and Sachs (1985), and the survey by McKibbin (1988)) that a policy coordination problem arises when the number of instruments is less than the number of targets. The paper by McKibbin analyses a single monetary instrument and two targets - output and prices. In the Nash game each player tries to gain by imposing losses on the other, by having a tight monetary policy and attempting to pursue disinflation by causing the exchange rate to appreciate, leading to cheaper import prices, thereby imposing currency depreciation and more expensive imports on other countries.

In the period after the GFC the cooperation issue was a different one. Vines $(2015,2016)$, and argues there were two objectives - full employment and public debt reduction - and one instrument, fiscal policy, since monetary policy had hit the zero bound. The result was that each country attempted to pursue fiscal consolidation coupled with currency depreciation so as to steal jobs from abroad-a

\footnotetext{
${ }^{4}$ Notice that the International Monetary Fund (IMF) operates in a top-down manner. A country with balance of payments difficulties first calls in the IMF, and then agrees to an 'IMF Programme' which sets out an agreement between the country in question and the IMF as to what the country is required to do in order to be lent money by the Fund. The country then also agrees to 'IMF conditionality' - by which is meant the idea money will only keep on flowing from Washington if the country actually does what the IMF Programme says it should do.
} 
repeat of the 'beggar thy neighbour' policies of the 1930s. The Nash outcome was too slow a recovery from the GFC. The cooperative outcome would have been less austerity. Of course, the fiscal position would have been worse under cooperation — but the problem with the Nash outcome was that the actual employment loss per unit fiscal gain was larger than policy-makers perceived that it would be.

In our simulations below we have one instrument-fiscal policy. What is the problem which makes cooperation necessary? What exactly is the global policy game?

\section{(ii) The structure of the policy game}

The game which we analyse is not a game of strategic interaction in which the Nash equilibrium is worse than the cooperative equilibrium because each of the players, lacking the necessary number of policy instruments, seeks to improve its own position by policy actions at the expense of other players (excessive monetary contraction in the first case described above; excessive fiscal contraction in the second case described above). Instead, we model the situation as being one in which several countries are held back from the fiscal support which they need by international financial pressure: the risk that international financial markets might take fright at the large budget deficits and current account deficits which would emerge, creating fiscal crises and/or currency crises, and so making it difficult to sustain the kind of policies of fiscal support which we advocate. So again there is a shortage of instruments: these countries cannot achieve what they want - a higher level of economic activity-because of the need to satisfy another objective, or constraint (a satisfactory external position or fiscal position), and the absence of a way to do this other than by not allowing fiscal support. What the process of cooperation does is to unbind that constraint (external or fiscal) in order to enable fiscal support to promote higher activity and employment. In other words, cooperation enables constrained countries to offset the severe economic contraction from the COVID-19 pandemic.

To model this global process it is convenient to divide all countries in the world into two groups: those which have been able to carry out the fiscal support which they desire (type 1), and those which have been held back from doing this by international financial pressure or institutional constraints on fiscal policy, such as being in a currency union (type 2). It is also useful to distinguish between advanced economies (type A) and emerging market and developing economies (type E). The complete list of countries and regions which must be dealt with in this division into groups and categories is listed in Table 2, which contains the disaggregation of the world economy in the G-Cubed (G20) model.

Among type A countries there are those, which we describe as falling into Group A1, which we treat as already having been able to carry out a significant degree of fiscal support. Perhaps this has not been enough (for various reasons in various countries), but we cannot say that these are countries in which the degree of fiscal support has been constrained by fears of excessive public debt or by fears of external imbalances. The majority of advanced economies fall into group A1; they are Australia, Canada, Germany, France, Japan, Korea, the UK, and the US. There will be those advanced economies which have not been able to do this and have been constrained in the fiscal support which they adopt. We call these countries group A2. This group includes Italy, because of the constraints which have been placed on Italy's capacity to act by the operating rules of the European Monetary Union, given 
Italy's extremely high level of public debt. We have also placed the rest of the Eurozone ${ }^{5}$ in this group for similar reasons, a group of countries which includes Spain, Portugal, and Ireland. ${ }^{6}$

We also divide emerging market and developing countries into two groups. The first group, consisting only of China, which we describe as group E1, we treat as already having been able to carry out a significant degree of fiscal support. This has perhaps not been enough (for China's own internal reasons), but we cannot say that China's fiscal policy has been constrained by fears of excessive public debt, or by fears of external imbalances, i.e.by the absence of international cooperation. But there have been many among emerging market and developing countries which have been constrained in this way and so have been constrained in the amount of fiscal support which they can adopt. We call these group E2. This group of countries consists of Argentina, Brazil, Indonesia, India, Mexico, Russia, Saudi Arabia, South Africa, Turkey, rest of Asia, other oil-producing countries, and the rest of the world.

We thus have:

Advanced countries Group A1: Australia, Canada, Germany, France, Japan, Korea, UK, US Advanced countries Group A2: Italy, Eurozone, ROECD

Emerging market and developing countries Group E1: China

Emerging market and developing countries group E2: Argentina, Brazil, Indonesia, India, Mexico Russia, Saudi Arabia, South Africa, Turkey, rest of Asia, other oil-producing countries, rest of the world

\section{(iii) The particular assumptions being made about the effects of cooperation}

Our policy exercise consists of two parts

(a) We simulate the effects of international policy coordination as being to allow a very large fiscal support in each of the Group 2 countries, both within advanced countries and within emerging market and developing countries, i.e. in both the A2 countries and the E2 countries.

This fiscal support is assumed to be achieved by means of a cut in the 'lump sum' taxes that fall on households. This fiscal expenditure lasts for 3 years, which is roughly as long as most of the COVID19 negative supply shocks last in the baseline simulation. That negative supply shock dies out gradually in the baseline simulation - it is roughly one-third gone in 2021, two-thirds gone in 2022, and all gone (apart from deaths) from then onwards. We implement the fiscal loosening to be gradually withdrawn according to the same time profile. The time profile of fiscal support is thus as follows:

Year 1 (2020): 6 per cent of GDP

Year 2 (2021): 4 per cent of GDP

Year 3 (2022): 2 per cent of GDP

Year 4 and onwards (2023 and onwards): zero.

\footnotetext{
${ }^{5}$ In the interests of brevity this group is called 'Eurozone' in the tables which follow.

${ }^{6}$ There is a problem here because this group of countries also includes some countries in the affluent North, including the Netherlands. But the version of the G-Cubed model used here does not allow for any finer disaggregation of countries within Europe than this.
} 
(b) In addition, we assume that greater cooperation in response to the COVID-19 crisis will result in a reduction in global risk that increased because of the virus.

In the Baseline simulation, which we describe in detail below, there are many shocks. Three shocks that represent higher risk are an increase in the country risk premium, the household risk premium, and the equity risk premium. These risk shocks vary across countries and are calibrated to the scale of the epidemiological shocks across all countries in year 1. In year 2 in the Baseline simulation, this COVID19 risk premium follows the pattern of the epidemiological assumptions - falling by a factor of half across all three kinds of risk premia, across all countries. In year 3 this COVID-19 risk premium is assumed to disappear, both in the case of country risk premia and household risk premia, but in the case of the equity risk premium, it is assumed to remain what it is in year 2, and an amount equal to half the original amount, for all years into the future. This captures the assumption that the virus is never eliminated. These risk premia are described in detail in Appendix A.

We assume that the second effect of international cooperation is to reduce all three risk premia by half in 2020 and 2021. In addition, the equity risk premium in year 3 is reduced to zero, so that, along with the household risk premium and the country risk premium, it remains at zero from then on. The argument is that the observation of international cooperation among policy-makers will reduce global risk as soon as the agreement is reached in 2020. This assumes that participants understand, right from the beginning of the simulation in year 1 , that this reduction in the equity risk premium happens.

The reduction in risk premia applies to all A1, A2, E1, and E2 countries even though the fiscal support only occurs in A2 and E2 economies.

\section{The G-Cubed (G20) model}

We carry out our investigations using the G-Cubed (G20) model. This is a particular version of the GCubed model which has been developed by Warwick McKibbin and Peter Wilcoxen since 1991 (McKibbin and Wilcoxen, 1999). It is documented by McKibbin and Wilcoxen (2013) in chapter 17 of Handbook of CGE Modeling (North Holland); see also McKibbin and Vines (2000). The most detailed and up-to-date description of the model can be found in McKibbin and Triggs (2018). The model has been used for policy analysis and scenario planning by governments, international agencies, corporations, banks, and academic researchers. Most recently, scenarios using the model and presented in McKibbin and Fernando (2020b) were unveiled along with the June 2020 update of the IMF's World Economic Outlook and the most recent edition of the World Bank's Global Economic Prospects volume in a virtual meeting held in Washington, DC and Canberra, Australia on 25 June 2020, a meeting at which the post-COVID state of the global macroeconomy was described and analysed.

Table 2 sets out the essential components of the model.

The model is a dynamic one, in which technical progress happens and capital accumulation takes place in each country. This means that the model is capable of analysing the global growth process. The model is deliberately an annual model, not a quarterly one. In the long run, resources are fully employed; labour is mobile across sectors in the economy, even in the short run, but not at all between countries. 
We can describe the model as a 'hybrid' model, using that term in the way in which it was used in papers, assembled in the Rebuilding Macroeconomic Theory Project, that were published in the January 2018 edition of the Oxford Review of Economic Policy (see Vines and Wills (2018), Blanchard (2018), and Wren-Lewis (2018)). The term 'hybrid' means that the model has both features of a microfounded DSGE model and features of a 'policy model' or 'structural economic model'.

Table 2: The G-Cubed (G20) model

Countries (20)
Argentina
Australia
Brazil
Canada
China
Rest of Eurozone
France
Germany
Indonesia
India
Italy
Japan
Korea
Mexico
Russia
Saudi Arabia
South Africa
Turkey
United Kingdom
United States

\author{
$\underline{\text { Regions (4) }}$ \\ Rest of the OECD \\ Rest of Asia \\ Other oil-producing countries \\ Rest of the world
}

Sectors (6)

Energy

Mining

Agriculture (including fishing and hunting)

Durable manufacturing

Non-durable manufacturing

Services

\section{Economic Agents in each Country (3)}

A representative household

A representative firm (in each of the 6 production sectors)

Government

Note: Model version documented in McKibbin and Triggs (2018).

The G-Cubed (G20) model includes all of the features of a micro-founded DSGE model: there are optimizing agents who are subject to two important frictions. In this sense the model is like the SmetsWouters (2007) model or the Christiano et al. (2005) model. There is a process of capital accumulation in each sector of the economy, in each country, driven by an investment function in which investment is subject to adjustment costs. This is the first of the major frictions. As a result of this friction, investment leads to a gradual adjustment of the capital stock over time; what happens is that investment responds to the value of Tobin's q, with 30 per cent of firms responding to a forward-looking q which evolves in a model-consistent manner with the remaining 70 per cent of firms having a backwardlooking q. The behaviour of some consumers (30 per cent) is driven by an Euler equation in which consumption in any period responds both to the contemporaneous real interest rate and to a forwardlooking expectation of future consumption (one which evolves in a model consistent manner). The remaining 70 per cent of consumers are liquidity constrained. There is a wage-setting process in which nominal wages are driven by a Calvo-Rotemberg-style Philips curve (in which some workers are backward looking); prices are set by profit-maximizing firms in each sector; these firms hire labour up 
to the point at which the marginal product of labour equals the real wage defined in terms of the output price level of that sector. As a result of these assumptions, nominal wages are sticky and adjust over time in a way which depends on labour-contracting assumptions, something which is allowed to differ from country to country. This gradual adjustment of wages is the second major friction in the model. Any excess supply of labour enters the unemployed pool of workers. Unemployment, or the presence of excess demand for labour, causes the nominal wage to adjust over time in a way which - taken in conjunction with the monetary rule and the behaviour of the nominal exchange rate-will ensure that the labour market clears in the long run. In the short run, unemployment can arise both because of structural supply shocks and because of changes to aggregate demand in the economy.

Monetary policy is implemented by supposing that the nominal interest rate is set according to a Henderson-McKibbin-Taylor (HMT) rule. ${ }^{7}$ In each country the rule adopted is programmed into the model in a way that is designed to approximate the actual monetary policy regime in that country. These monetary rules tie down the long-run inflation rates in each country as well as allowing for short-term adjustments of monetary policy, by means of interest rate changes, that are carried out in order to damp down fluctuations in the real economy.

We have already made clear that, like in the Smets-Wouters model and in the Christiano et al. model, there are two fundamental frictions in the model. One is in the process of capital accumulation (because of adjustment costs in the investment function), and the other is in the inflationary process (because of the overlapping nature of the wage-setting process). Together these two features mean that the model has new-Keynesian features and does not behave, in the short run, like a real business cycle (RBC) model. But crucially, in the long run the model does have RBC properties. As we will see, these properties are fundamental to the analysis which is described in this paper.

Nevertheless, the model is a 'hybrid' one. It is much closer than most DSGE models to what Blanchard (2018) calls a policy model, or what Wren Lewis (2018) calls a structural economic model. There are several aspects to this resemblance. First, the model pays attention to the need to disaggregate output into a number of different sectors, whose relative prices may move during simulation. Six different sectors are identified. ${ }^{8}$ In addition, the model captures inter-industry linkages (in that some of the output of some industries serves as inputs into other industries), and it treats the price of energy and mining as determined in a different manner from that of manufactured goods or services. ${ }^{9}$ Because of this there are many features of the model's behaviour which will be familiar to those who have experience with using computable general equilibrium (CGE) models.

Being a global model, the model needs to capture the effects of international trade and of international capital flows. Trade balances are determined by properly modelled export functions and import functions for each country, which map consistently into the equations for imports and exports in other countries; changes in real exchange rates between countries have significant and important influences on trade flows between countries within the model. The model supposes perfect international mobility

\footnotetext{
${ }^{7}$ See Henderson and McKibbin (1993) and Taylor (1993).

${ }^{8}$ The sectors are energy, mining, agriculture, durable manufacturing, non-durable manufacturing, and services.

${ }^{9}$ Allowing for changes in the relative prices of the goods produced in these six sectors has been absolutely fundamental in modelling the Baseline simulation for the present study, essentially because the prices of energy and mining have suffered catastrophic downturns as a result of the COVID-19 shock.
} 
of capital between countries, and the exchange rate is determined, $\grave{a}$ la Dornbusch, by the uncovered interest parity (UIP) condition, except for countries having pegged exchange rates and for those countries within the European Monetary Union. But there is explicit allowance for risk premia in these UIP equations.

As already noted, the nominal interest rate in each country follows an HMT rule in most countries; in these countries the exchange rate floats. But in some countries, including those within the European Monetary Union and Saudi Arabia, exchange rates are fixed or pegged, and the interest rate is tied down by international conditions. For China the exchange rate has a managed float; although the central bank operates an HMT rule, there is an exchange rate term in this rule.

Furthermore, the model shows appropriate respect for impediments to the smooth functioning of markets which go beyond the two major frictions already mentioned, but which are not easy to microfound. These impediments include the liquidity constraints and backward-looking behaviour which we have already mentioned. But in addition, serious attention is given to the importance of risk premia. All simulations of the model require assumptions to be made about (i) the country risk premium for each and every country relative to the US, (ii) the risk premium which consumers apply in calculating the present value of their accumulated wealth, and (iii) the equity risk premium for each of the six sectors in each country. But these assumptions about risk premia are-very deliberately — treated as exogenous to the simulation in question.

Three further features of the model have an important influence on the results which we present.

First, the model completely accounts for stocks and flows of physical and financial assets. For example, budget deficits accumulate into government debt, and current account deficits accumulate into foreign debt. The model imposes an intertemporal budget constraint on all households, firms, governments, and countries. This means that, in the long-run equilibrium of the model, to which all simulations must tend, the level of asset prices which emerges must be consistent with the long-run supply of assets, so that economic agents actually wish to hold the assets which are in existence. Thus in such a long-run equilibrium the current account of every country must stabilize; this has implications for the long-run real exchange strange rate. Furthermore, the interest rate on government fiscal positions must be consistent with private-sector agents wishing to hold the outstanding stock of government debt. And the stock of physical capital must have adjusted in all sectors so that the value of Tobin's q in each sector is equal to or very close to unity, after allowing for effects of corporate tax rates. However, the adjustment towards the long-run equilibrium in each economy can be very slow, occurring over much of a century.

Second, the model incorporates heterogeneous households and firms. Firms are modelled separately within each sector. And, as already noted, within each country the model assumes two types of consumers, and two types of firms within each sector. One group of consumers and firms bases its decisions on forward-looking model-consistent expectations. The other group follows simple rules of thumb which are only optimal in the long run.

Third, rigidities prevent the economy from moving quickly from one equilibrium to another. These rigidities include the nominal stickiness caused by wage rigidities, and the costs of adjustment in investment by firms. The latter kinds of costs mean that physical capital is sector-specific in the short run. But in the longer term physical capital moves between sectors, and between countries, so as to 
equalize risk-adjusted rates of return around the world. ${ }^{10}$ As we will see, this process of international reallocation of capital is a profoundly important part of the adjustment process, in response to the policy changes which we investigate. The adjustment path in the model is also affected by a lack of complete foresight in the formation of expectations, and by monetary and fiscal authorities following particular monetary and fiscal rules. Short-term adjustment to economic shocks can be very different from the long-run equilibrium outcomes. The focus on short-run rigidities is essential for assessing the impact over the first 5 years after a major shock - the kind of time period on which we concentrate below. This point is especially important given - as noted above - the extremely long time which the model takes to move towards its long-run equilibrium after any shock is applied to it.

\section{The modelling strategy}

\section{(i) An important preliminary point about global aggregate supply and global aggregate demand in the Baseline Scenario}

We first note an important preliminary point.

Guerrieri et al. (2020) suggest that a supply shock like that caused in the COVID-19 pandemic cannot cause aggregate demand to fall as much as aggregate supply. Their argument is located within an impressive micro-founded new-Keynesian set-up. But stripped back, it depends on the claim that the marginal propensity to consume will be less than one when any short-run fall in output and income is more than the long-run fall is going to be, for what are essentially consumption-smoothing reasons. ${ }^{11}$ But this claim has to be misleading; there is an important point at stake here. In a model like G-Cubed (G20), if the negative supply shock is expected to last for long enough, it will lead to such a large reduction in investment that, after also allowing for any fall in consumption caused by the fall in output and thus in the income of consumers, aggregate demand may fall by much more than the fall in aggregate supply. This is a key feature of the results in McKibbin and Fernando (2020b) which we describe below.

The results that follow also reflect our assumption that, in the absence of the kind of international cooperation which is studied in the present paper, the COVID-19 shock is likely to give rise to an ongoing increase in the risk premium attached to investment. This will cause a reduction in aggregate demand in addition to any effects on aggregate demand of the supply shock which COVID-19 causes. This is another reason why there is a very large reduction in investment and so output in the near term in the Baseline Scenario results.

\footnotetext{
${ }^{10}$ Such 'movement' of capital happens because in sectors in which Tobin's q is above unity, net investment is positive and the stock of physical capital accumulates, whereas in sectors where Tobin's q is below unity, depreciation leads the stock of physical capital to decumulate.

11 Their claim is that to get Keynesian features in which demand falls more than supply you need to carry out the analysis using a model which contains more than one sector. In some sectors the outcome will be supply constrained; the loss of income to those employed in those sectors will cause a fall in their demand for the output of goods produced in the other sectors, in which supply is not constrained. Clearly for those other sectors, demand may fall more than supply. But for reasons explained in the text, this feature is not necessary for one to obtain 'Keynesian' demand-shortage features in response to a COVID-19 shock. But these sectorial problems will - of course-add further to the problems which that shock causes.
} 


\section{(ii) Implementing the global shocks in the G-Cubed (G20) model}

Our aim is to investigate the effects of international cooperation. But we are taking as a Baseline Scenario, on top of which we construct our analysis of the effects of cooperation, our estimate of where the world actually is now. In section II(i) above we presented our understanding of this starting position. In order to create such an estimate we need to convert our knowledge of the features of the pandemic into a set of economic shocks to input into the G-Cubed (G20) model. All this work has already been done by Warwick McKibbin and Roshen Fernando, and is described in McKibbin and Fernando (2020b).

We now provide a very brief sketch of what has been done to construct this baseline. The text which follows should be read in conjunction with Figures A1 to A5 in Appendix A. These figures provide a schematic illustration of how the inputs to the model are constructed. We interpret the COVID-19 pandemic as a series of economic shocks. We use the term 'shocks' to describe the impact of the COVID-19 pandemic on the behaviour of households, firms, and government not captured by the equations of the model. The major economic shocks are: the reduction in labour force, due to mortality and illness, and including the effects of needing extra carers (Figure A1); a shift in consumers' preferences (Figure A2); an increase in business costs, differentiated by sector (Figure A3); shutdowns in large parts of some economies (Figure A3); disruption of production chains (Figure A3); reevaluation of sector and country risks (Figures A3 and A4); and the fiscal policy responses (Figure A5). We then turn these shocks into inputs into the model according to the sequence of steps laid out in the figures. Full details can be found in McKibbin and Fernando (2020b).

The model endogenously determines the automatic fiscal stabilizers and the monetary policy responses when simulating the effects of these shocks.

\section{(iii) The baseline and an initial look at the effects of cooperation}

Section II(i) showed our best guess of the starting point from which we begin, what we call our Baseline Scenario, an outcome which is obtained by putting all of the shocks just described into the model. We start our analysis from the position of current policies as of June 2020. It is useful to focus on a country from group A2 (Italy) and a country from group E2 (Brazil) to outline what the overall macroeconomic outcomes will look like for the next 6 years. (See Figures 2 and 3, which make use of the detailed results provided McKibbin and Fernando (2020b).) As already noted, we assume that G20 cooperation results in two things: (i) fiscal support and (ii) the understanding of a cooperative response to the COVID-19 pandemic which instils confidence and therefore reduces global risk premia. In particular, we reduce the risk premia in the calculation of human wealth by households in the equity risk premia of individual sectors, and the country risk premia. All country risk is relative to the US. The precise details of what has been done have already been explained in section IV(iii). We do not change any other shocks which have been introduced into the model to capture the COVID-19 pandemic. In particular we do not change consumer preferences for the output of different sectors of the economy, which have, of course, been adjusted in the calculation of the Baseline Scenario.

We now describe these results for Italy and Brazil. 
Figure 2: Baseline compared to baseline with G20 cooperation: Italy
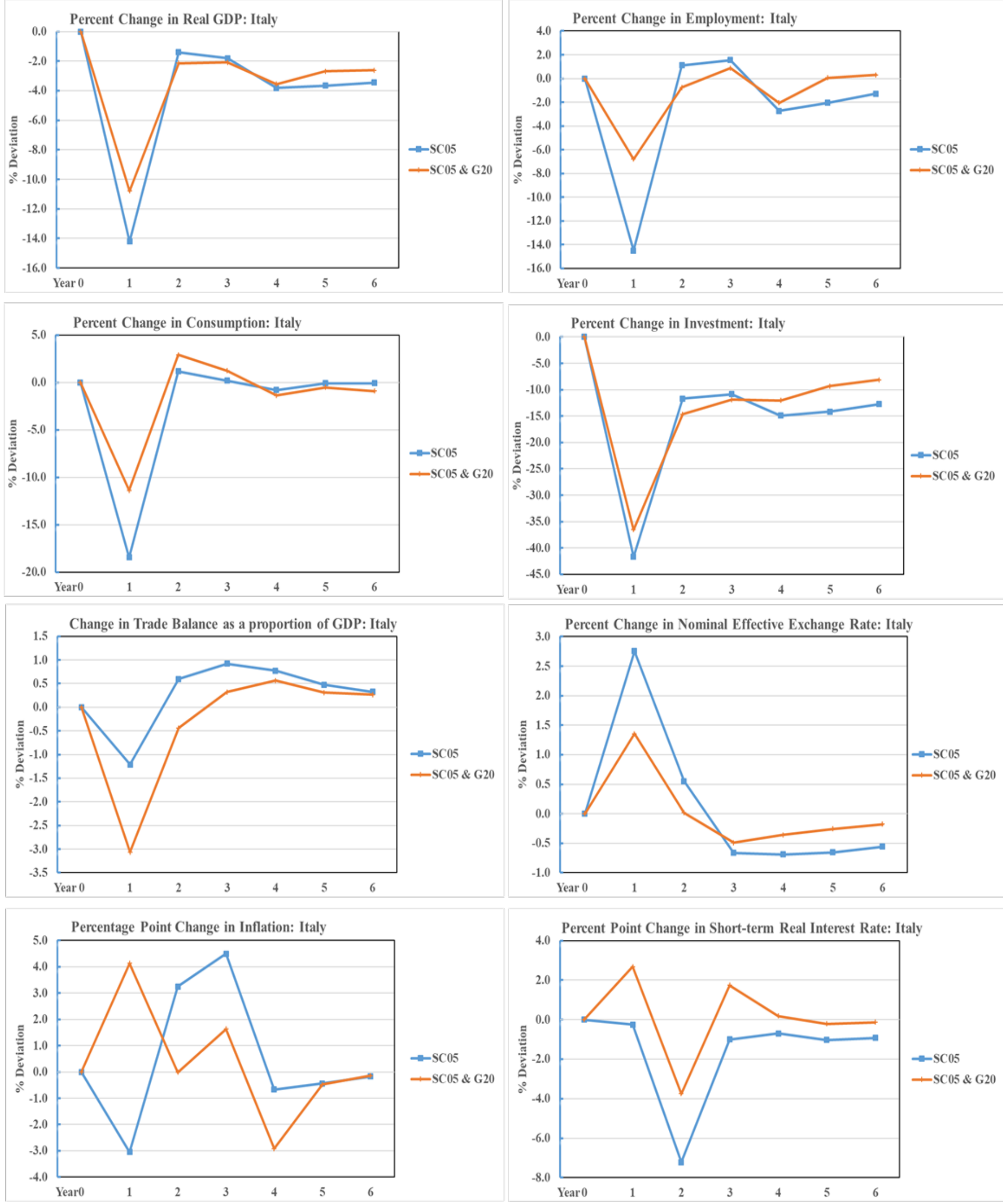
Figure 3: Baseline compared to baseline with G20 cooperation: Brazil
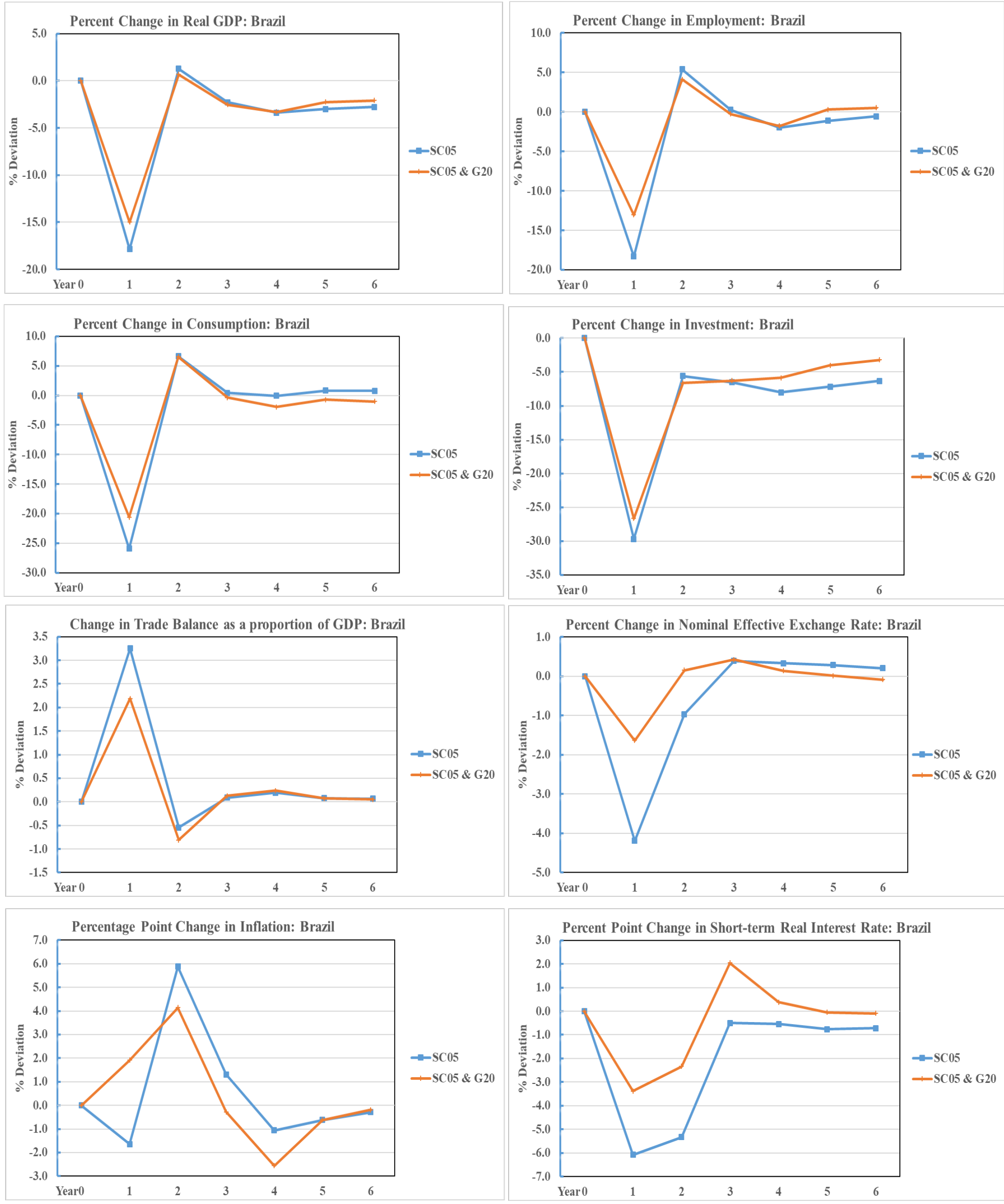
Figures 2 and 3 contains the results for eight macroeconomic variables under two scenarios. The first scenario is our baseline (scenario 05 from McKibbin and Fernando (2020b)) which shows the impact of the COVID-19 shock on each variable relative to what it would have been in the no-COVID-19 world. These are per cent deviations from the no-COVID-19 world for GDP, employment, consumption, investment, nominal effective exchange rate, per cent of GDP deviation in the trade balance, and percentage point deviation of inflation and the short-term real interest rate. This scenario is called SC05 and is the blue line with the square symbol.

The second scenario is the result for the same variables under the full G20 cooperation scenario which we analyse in detail in what follows. This cooperation scenario assumes both fiscal support in all A2 and $\mathrm{E} 2$ countries and a reduction in global risk in all countries.

Figure 2 shows the large shock in Italy from the COVID-19 pandemic and the current policy changes in Italy. It also shows that the alternative outcome when there is G20 cooperation is substantially improved. The improvement is close to 4 per cent of GDP in 2020. Although this is dwarfed by the overall shock which has reduced Italian GDP by 14 per cent, it is a substantial improvement. The employment benefits of the policy are even more substantial, reducing the sharp decline in employment in 2020 from 14 per cent to 6 per cent. It also leads to better outcomes for most other variables. Importantly the trade balance deterioration is larger, with an increase in the trade deficit of 3 per cent of GDP rather than 1 per cent of GDP which occurs without the G20 cooperation. This increase in the trade deficit occurs because, once the financing constraint on Italy is removed, thus enabling a temporary tax cut, spending output and imports all increase and so the trade balance worsens. Overall the improvement in GDP for Italy from G20 cooperation is close to 4 per cent of GDP in 2020.

Figure 3 shows the same two scenarios for Brazil as representative of group E2 countries. The story is similar to the results for Italy, but with several interesting differences. Italy is part of the Eurozone and therefore monetary policy is tied to the monetary policy of the Eurozone which responds to developments not just in Italy but in the whole of the Eurozone, including Germany. Since Germany is not changing fiscal policy, the constraint of the currency peg means that, as the Italian currency would otherwise appreciate, monetary policy in Italy is looser than it would have been if Italy had been operating an independent monetary policy with a floating exchange rate which, in those other circumstances, would have appreciated. Thus, Italy has both fiscal support and the equivalent of a monetary relaxation due to the tying of Italian interest rates to the rest of Europe. Thus the GDP and employment gains for Brazil are much smaller than those for Italy because Brazil has an independent monetary policy and interest rates tend to be higher in Brazil under the G20 scenario, but still, of course, lower than they would have been had there not been a COVID-19 pandemic. Second, Brazil experiences a trade surplus during the COVID-19 pandemic because financial capital flows out of Brazil, given its large reliance on foreign denominated external debt and its heavy exposure to the collapse in global trade which the pandemic causes, especially through commodity trade. ${ }^{12}$ The G20 cooperation still implies a trade surplus from the COVID-19 shock, but a somewhat smaller trade surplus under G20 cooperation because less capital flows out of Brazil, since real interest rates are

\footnotetext{
12 The G-Cubed (G20) model is able to incorporate this outcome because of the disaggregation of output in the model into six sectors; the model faithfully captures the collapse in the price of energy and of mining output which has occurred during the COVID-19 pandemic.
} 
higher than they would have been. Nevertheless, the improvement in GDP for Brazil from G20 cooperation is close to 3 per cent of GDP in 2020.

\section{Summary of results}

In section VI above, we described the Baseline Scenario on which we are overlaying G20 cooperation and we very briefly summarized the outcomes of that cooperation for Italy and Brazil. The scale of the crisis dominated the figures. In this section, and in what follows, we will very deliberately focus on the difference between the cooperative outcomes and the Baseline Scenario.

Table 3 contains a summary of the findings of this paper.

Table 3: Summary of changes in macroeconomic variables in 2020 across country groups

\begin{tabular}{lrrrrr}
\hline & \multicolumn{1}{c}{$\begin{array}{c}\text { A1 } \\
\text { Countries }\end{array}$} & $\begin{array}{c}\text { A2 } \\
\text { Countries }\end{array}$ & $\begin{array}{c}\text { E1 } \\
\text { Countries }\end{array}$ & $\begin{array}{c}\text { E2 } \\
\text { Countries }\end{array}$ & $\begin{array}{c}\text { All } \\
\text { Countries }\end{array}$ \\
\hline Real GDP (\$USBil) & $\$ 437$ & $\$ 137$ & $\$ 116$ & $\$ 487$ & $\$ 1,178$ \\
$(\%)$ & $1.39 \%$ & $2.71 \%$ & $1.06 \%$ & $2.24 \%$ & \\
Employment (\%) & $2.60 \%$ & $7.82 \%$ & $2.14 \%$ & $5.13 \%$ & \\
Fiscal Position & & & & & \\
$\quad$ Budget Deficit & & & & & \\
$\quad$ \$USBil & $\$ 58$ & $-\$ 424$ & $\$ 25$ & $-\$ 1,311$ & $-\$ 1,651$ \\
$\quad$ Ratio to GDP & $-0.26 \%$ & $7.92 \%$ & $-0.31 \%$ & $5.76 \%$ & \\
$\quad$ Government Debt by 2025 & & & & & \\
$\quad$ \$USBil & $\$ 61$ & $\$ 908$ & $-\$ 118$ & $\$ 2,651$ & $\$ 3,502$ \\
$\quad$ Ratio to GDP & $-1.13 \%$ & $15.03 \%$ & $-2.31 \%$ & $10.10 \%$ & \\
External Position & & & & & \\
$\quad$ Trade Deficit (\$USBil) & $\$ 767$ & $-\$ 162$ & $\$ 109$ & $-\$ 715$ & $\$ 0$ \\
$\quad$ Foreign Debt by 2025(\$USBil) & $-\$ 1,892$ & $\$ 241$ & $-\$ 261$ & $\$ 1,911$ & $\$ 0$ \\
\hline
\end{tabular}

Key: Advanced countries Group A1: Australia, Canada, Germany, France, Japan, Korea, UK, US Advanced countries Group A2: Italy, Eurozone, ROECD

Emerging Market and Developing countries Group E1 China

Emerging Market and Developing countries group E2: Argentina, Brazil, Indonesia, India, Mexico Russia, Saudi Arabia, South Africa, Turkey, Rest of Asia, Other Oil Producing Countries, Rest of the world

Recall that the fiscal action in those countries undertaking fiscal support is reductions in lump-sum taxes with the following time profile:

Year 1 (2020): 6 per cent of GDP

Year 2 (2021): 4 per cent of GDP

Year 3 (2022): 2 per cent of GDP

This table reports the difference between the 'full G20 scenario' (i.e. with coordination) and the baseline. 
In sum, fiscal support of the kind that we describe in this paper would make a very large difference to the world. Our simulations suggest that GDP in the countries in which fiscal support takes place would be something like two and a half per cent higher in the first year, and that GDP in other countries in the world be more than 1 per cent higher. Employment in the stimulating countries would go up by a very much larger percentage than this because with nominal wages fixed in 2020, a rise in inflation on average would reduce real wages. At the sectoral level there are shifts in relative prices so that real wages move differently across the sectors. The sectors that produce capital goods or goods that go directly into higher investment (energy, mining, durable manufacturing goods) would experience a rise in demand and therefore in prices. For some countries the relatively higher global demand resulting from the policy would raise commodity prices and therefore reduce real wages in commodity sectors (agriculture, mining). Thus, real wages would fall particularly in a number of sectors in 2020, thereby stimulating employment.

The implications for the fiscal positions of countries are very large. In emerging market and developing countries the total of the increase in public debt over a period of 5 years would be nearly three trillion dollars - an increase in the ratio of public debt to GDP of more than 10 per cent of GDP. The increase in public debt in those advanced countries in which fiscal support happens - of which Italy is the largest-would be of the order of 15 per cent of GDP. This fiscal action would cause very large movements in trade balances and so in foreign debts; it would lead to an increase in the outstanding foreign debt of emerging market economics and of developing countries which together add up to nearly two trillion dollars.

It is worth standing back from these aggregate results and asking how it is that they actually come about. The world as a whole experiences two kinds of stimuli as a result of the global cooperation process which we are studying. First there is a temporary period in which there is enhanced fiscal support in some countries. And second there is a reduction in global risk, most pronounced in the short term, but - in the case of the equity risk premium - long lasting; this reduction in global risk causes an increase in both investment and consumption. What are the global macroeconomic consequences of these shocks?

The fiscal support in some countries causes global inflation to be higher than in the Baseline Scenario. As a result, global real interest rates are higher, because of the operation of the HMT rule for monetary policy in the face of increased demand and output. The tax cuts mean that there is a very great increase in global public debt; the G-Cubed (G20) model supposes that this will be reduced only very slowly, long after the time period being studied in this paper. The long-lasting increase in investment, caused by the reduction in global risk, causes a long-lasting increase in the stock of physical capital and so in worldwide potential output.

Of course there are differences between the outcomes in countries in which the fiscal support takes place and the outcomes in which it does not. Standard Mundell-Fleming type analysis suggests that, in the former group of countries, real interest rates will be higher, because of the operation of the HMT rule for monetary-policy, and the real exchange rate will appreciate, causing some crowding out of the effects of the fiscal support. 
There are also differences between countries in which the reduction in risk premia is the greatest, compared with the others. The increase in investment, and so the gradual increase in the physical capital stock, will be is largest in the former group of countries. These countries will experience the greatest increase in supply potential, which of course will improve tax revenues and so ameliorate their fiscal position in the medium term. By contrast the other countries will tend to experience higher real interest rates, simply because real interest rates are higher world-wide, which will depress investment. That will gradually lower the capital stock and potential output, and reduce tax revenues, thereby tending to worsen the fiscal position in the medium term.

We now turn to examining more detailed effects, country by country.

\section{Results for all countries}

\section{(i) Detailed results for all countries}

The detailed results are set out in a series of tables. These tables show results for all countries, for what we call the 'full G20 scenario', that is to say the combined effects of the fiscal support in the A2 and E2 groups of countries and the effects of the reduction in global risk premia; these are the two components of what we assume to be the effect of the process of G20 collaboration. The results in these tables and figures from here on depict the difference between the 'full G20 scenario' (i.e. the one with coordination) and the Baseline Scenario.

These tables are followed by a set of figures which show the dynamic adjustment path for a subset of countries from each the four groups of countries which we have identified. In these figures we draw two lines. The first line separately identifies the effect, relative to the Baseline Scenario, of the fiscal support, on its own, in the A2 and E2 groups of countries. The second line shows the effect, relative to the Baseline Scenario, when this fiscal support is combined with the effects of a reduction in global risk. We identify the effects separately in order to make clear the relative contributions of both aspects of the $\mathrm{G} 20$ policy cooperation process.

Table 4 shows the change in fiscal deficits for all countries from the full G20 scenario from 2020 to 2025 , as well as the cumulative sum of fiscal deficits which approximates to the change in public debt which occurs over the period. These results are for the full G20 cooperation scenario. The total amount of global debt generated in 2020 is over \$US1.7 trillion and the cumulative amount of government debt created by 2025 is \$US3.7 trillion. Interestingly, while the fiscal deficits of group A2 and E2 countries rise in 2020, as expected, because they are undertaking a policy of fiscal support, the initial fiscal deficits of group A1 and E1 countries fall because the overall policy of G20 cooperation leads to stronger economic growth globally relative to baseline. Thus from 2020 and into 2022 fiscal deficits in A1 and E1 countries improve substantially. By 2023 the fiscal support is removed, and the fiscal position worsens in $\mathrm{A} 1$ and $\mathrm{E} 1$ countries.

Table 5 contains the same data for fiscal deficits but now scaled by GDP. This shows the large difference in the \$US change in fiscal deficits across countries, something which largely reflects the difference in the size of economies. Recall that the temporary tax cuts are the same share of GDP in all stimulating economies. The changes in the fiscal deficit for stimulating countries are mostly less 
than the amount of tax cuts given, due to endogenous changes in the economies as a result of the fiscal support: activity rises and so tax revenues increase and transfer payments to the unemployed fall.

Table 6 shows the change in trade balances as a per cent of GDP, in \$US and cumulated in \$US from 2020 to 2025. All stimulating countries experience a deterioration in their trade balances and all such countries therefore experience capital inflow. These countries are effectively borrowing abroad to fund at least some of their temporary fiscal deficits. Of course, the deficits which emerge in these countries lead to surpluses in other countries. The most major surpluses which emerge are as follows: US \$437 billion; Europe as a whole, US\$168 billion; and China US\$109 billion.

Table 7 contains the change in the current accounts of simulating economies from 2020 to 2025 as well as the cumulative total or the change in external debt.

Table 4: Change in fiscal deficit in \$2015US billion

\begin{tabular}{lrrrrrrr}
\hline \multicolumn{1}{c}{ Country/Region } & $\mathbf{2 0 2 0}$ & $\mathbf{2 0 2 1}$ & $\mathbf{2 0 2 2}$ & $\mathbf{2 0 2 3}$ & $\mathbf{2 0 2 4}$ & $\mathbf{2 0 2 5}$ & Cumulative \\
\hline USA & -7 & -256 & -49 & 145 & 211 & 197 & 241 \\
Japan & -23 & -33 & 7 & 34 & 40 & 34 & 58 \\
Germany & -5 & -52 & -15 & 22 & 37 & 29 & 17 \\
United Kingdom & -3 & -25 & -13 & 4 & 17 & 18 & -2 \\
France & -5 & -19 & 5 & 23 & 29 & 25 & 59 \\
Italy & 97 & 28 & 25 & 14 & 24 & 20 & 207 \\
Rest of Euro Zone & 213 & 69 & 61 & 39 & 63 & 56 & 502 \\
Canada & -2 & -8 & -1 & 4 & 6 & 7 & 6 \\
Australia & -3 & -8 & 1 & 5 & 5 & 4 & 2 \\
Rest of OECD & 114 & 39 & 28 & 18 & 35 & 29 & 264 \\
South Korea & -10 & -8 & 0 & 5 & 6 & 8 & 1 \\
Turkey & 41 & 20 & 11 & 0 & 2 & 1 & 76 \\
China & -25 & -90 & -30 & 10 & 19 & 18 & -99 \\
India & 132 & 64 & 36 & 10 & 23 & 23 & 289 \\
Indonesia & 54 & 27 & 17 & 5 & 7 & 5 & 115 \\
Other Asia & 100 & 60 & 39 & 12 & 14 & 13 & 238 \\
Mexico & 69 & 42 & 25 & 5 & 6 & 5 & 152 \\
Argentina & 30 & 10 & 5 & 1 & 5 & 4 & 56 \\
Brazil & 110 & 38 & 29 & 15 & 28 & 25 & 246 \\
Russia & 74 & 36 & 23 & 6 & 11 & 9 & 159 \\
Saudi Arabia & 28 & 9 & 9 & 4 & 7 & 6 & 63 \\
South Africa & 18 & 10 & 7 & 4 & 6 & 6 & 52 \\
Rest of World & 471 & 251 & 134 & 21 & 54 & 47 & 979 \\
Rest of OPEC & 182 & 95 & 45 & 0 & 13 & 11 & 346 \\
World Total & 1651 & 299 & 402 & 406 & 669 & 599 & 4026 \\
Total of Stimulating Countries & $\mathbf{1 7 3 5}$ & $\mathbf{7 9 8}$ & $\mathbf{4 9 6}$ & $\mathbf{1 5 5}$ & $\mathbf{3 0 0}$ & $\mathbf{2 5 9}$ & $\mathbf{3 7 4 2}$ \\
\hline
\end{tabular}


Table 5: Change in fiscal deficit as \% GDP

\begin{tabular}{|c|c|c|c|c|c|c|}
\hline Country/Region & 2020 & 2021 & 2022 & 2023 & 2024 & 2025 \\
\hline USA & $-0.10 \%$ & $-1.32 \%$ & $-0.26 \%$ & $0.81 \%$ & $1.16 \%$ & $1.06 \%$ \\
\hline Japan & $-0.66 \%$ & $-0.67 \%$ & $0.15 \%$ & $0.65 \%$ & $0.72 \%$ & $0.60 \%$ \\
\hline Germany & $-0.21 \%$ & $-1.43 \%$ & $-0.40 \%$ & $0.62 \%$ & $1.02 \%$ & $0.79 \%$ \\
\hline United Kingdom & $-0.22 \%$ & $-0.80 \%$ & $-0.40 \%$ & $0.14 \%$ & $0.51 \%$ & $0.52 \%$ \\
\hline France & $-0.27 \%$ & $-0.70 \%$ & $0.20 \%$ & $0.90 \%$ & $1.08 \%$ & $0.91 \%$ \\
\hline Italy & $4.98 \%$ & $1.41 \%$ & $1.16 \%$ & $0.57 \%$ & $0.91 \%$ & $0.72 \%$ \\
\hline Rest of Euro Zone & $5.73 \%$ & $1.72 \%$ & $1.49 \%$ & $0.94 \%$ & $1.50 \%$ & $1.29 \%$ \\
\hline Canada & $-0.24 \%$ & $-0.48 \%$ & $-0.06 \%$ & $0.22 \%$ & $0.37 \%$ & $0.41 \%$ \\
\hline Australia & $-0.44 \%$ & $-0.60 \%$ & $0.05 \%$ & $0.31 \%$ & $0.29 \%$ & $0.24 \%$ \\
\hline Rest of OECD & $5.85 \%$ & $1.83 \%$ & $1.28 \%$ & $0.85 \%$ & $1.60 \%$ & $1.30 \%$ \\
\hline South Korea & $-0.73 \%$ & $-0.47 \%$ & $0.03 \%$ & $0.26 \%$ & $0.31 \%$ & $0.36 \%$ \\
\hline Turkey & $5.60 \%$ & $2.48 \%$ & $1.24 \%$ & $0.07 \%$ & $0.24 \%$ & $0.15 \%$ \\
\hline China & $-0.31 \%$ & $-0.69 \%$ & $-0.21 \%$ & $0.06 \%$ & $0.10 \%$ & $0.10 \%$ \\
\hline India & $5.76 \%$ & $2.35 \%$ & $1.21 \%$ & $0.31 \%$ & $0.59 \%$ & $0.52 \%$ \\
\hline Indonesia & $5.70 \%$ & $2.47 \%$ & $1.46 \%$ & $0.36 \%$ & $0.45 \%$ & $0.31 \%$ \\
\hline Other Asia & $5.88 \%$ & $3.06 \%$ & $1.92 \%$ & $0.55 \%$ & $0.63 \%$ & $0.53 \%$ \\
\hline Mexico & $5.57 \%$ & $2.93 \%$ & $1.66 \%$ & $0.29 \%$ & $0.30 \%$ & $0.20 \%$ \\
\hline Argentina & $6.69 \%$ & $1.70 \%$ & $0.81 \%$ & $0.12 \%$ & $0.72 \%$ & $0.58 \%$ \\
\hline Brazil & $6.17 \%$ & $1.67 \%$ & $1.17 \%$ & $0.54 \%$ & $0.89 \%$ & $0.72 \%$ \\
\hline Russia & $5.93 \%$ & $2.44 \%$ & $1.48 \%$ & $0.40 \%$ & $0.61 \%$ & $0.46 \%$ \\
\hline Saudi Arabia & $4.17 \%$ & $1.33 \%$ & $1.31 \%$ & $0.62 \%$ & $0.88 \%$ & $0.78 \%$ \\
\hline South Africa & $6.48 \%$ & $2.62 \%$ & $1.65 \%$ & $0.82 \%$ & $1.01 \%$ & $0.87 \%$ \\
\hline Rest of World & $5.91 \%$ & $2.78 \%$ & $1.43 \%$ & $0.21 \%$ & $0.51 \%$ & $0.42 \%$ \\
\hline Rest of OPEC & $5.32 \%$ & $2.56 \%$ & $1.12 \%$ & $-0.02 \%$ & $0.24 \%$ & $0.17 \%$ \\
\hline World Total & $2.28 \%$ & $0.35 \%$ & $0.46 \%$ & $0.45 \%$ & $0.72 \%$ & $0.62 \%$ \\
\hline
\end{tabular}

Table 6: Change in trade balances of stimulating countries in \% GDP and \$2015US billion

\begin{tabular}{|c|c|c|c|}
\hline Country/Region & $\begin{array}{c}2020 \\
\% \text { GDP }\end{array}$ & $\begin{array}{l}2020 \\
\text { \$US }\end{array}$ & $\begin{array}{c}\text { Cumulative } \\
2020-25\end{array}$ \\
\hline Italy & -2.0 & -37 & -83 \\
\hline Rest of Euro Zone & -2.0 & -68 & -105 \\
\hline Rest of OECD & -3.0 & -57 & -137 \\
\hline Turkey & -1.3 & -9 & 10 \\
\hline India & -3.3 & -73 & -140 \\
\hline Indonesia & -0.8 & -7 & 17 \\
\hline Other Asia & -2.8 & -46 & -52 \\
\hline Mexico & -2.6 & -31 & -25 \\
\hline Argentina & -2.1 & -9 & -12 \\
\hline Brazil & -1.3 & -22 & -27 \\
\hline Russia & -2.9 & -32 & -66 \\
\hline Saudi Arabia & -0.7 & -8 & -5 \\
\hline South Africa & -5.5 & -15 & -31 \\
\hline Rest of World & -4.5 & -348 & -473 \\
\hline Rest of OPEC & -5.3 & -175 & -455 \\
\hline Total & & -939 & $-1,584$ \\
\hline
\end{tabular}


Table 7: Change in current accounts of stimulating countries in \$2015US billion

\begin{tabular}{lrrrrrrr}
\hline Country/Region & $\mathbf{2 0 2 0}$ & $\mathbf{2 0 2 1}$ & $\mathbf{2 0 2 2}$ & $\mathbf{2 0 2 3}$ & $\mathbf{2 0 2 4}$ & $\mathbf{2 0 2 5}$ & Cumulative \\
\hline Italy & -34 & -17 & -10 & -5 & -5 & -3 & -73 \\
Rest of Euro & -71 & -46 & -19 & 2 & -1 & -1 & -136 \\
Zone & -28 & -16 & -2 & 5 & 4 & 2 & -34 \\
Rest of OECD & -19 & -11 & -2 & 5 & 3 & 2 & -22 \\
Turkey & -1 & -6 & -21 & -20 & -28 & -33 & -110 \\
India & 18 & 23 & 11 & 15 & 10 & 7 & 83 \\
Indonesia & -48 & 4 & -13 & 5 & 1 & -4 & -56 \\
Other Asia & 59 & 19 & -8 & 0 & -8 & -14 & 48 \\
Mexico & 22 & 10 & 7 & 7 & 4 & 3 & 54 \\
Argentina & 84 & 55 & 19 & 15 & 5 & -2 & 176 \\
Brazil & 6 & -19 & -8 & 0 & -4 & -5 & -30 \\
Russia & -26 & -14 & -3 & 4 & 5 & 5 & -29 \\
Saudi Arabia & -11 & 5 & -1 & -3 & -6 & -7 & -23 \\
South Africa & 63 & -33 & -105 & -18 & -26 & -32 & -152 \\
Rest of World & -205 & -72 & -21 & -14 & -21 & -21 & -355 \\
Rest of OPEC & $\mathbf{- 1 9 2}$ & $\mathbf{- 1 1 8}$ & $\mathbf{- 1 7 6}$ & $-\mathbf{4}$ & $\mathbf{- 6 6}$ & $\mathbf{- 1 0 6}$ & $\mathbf{- 6 6 0}$ \\
Total & & & & & & & \\
\hline
\end{tabular}

\section{(ii) Dynamic results for a selection of countries}

The dynamic results for a selection of countries in each group are contained in a series of figures: Figure 4 for the United States, Figure 5 for Germany, Figure 6 for Italy, Figure 7 for China, and Figure 8 for Indonesia. The figures contain the results for same eight macroeconomic variables which we identified in the previous figures, namely GDP, employment, consumption, investment, nominal effective exchange rate, per cent of GDP deviation in the trade balance, percentage point deviation of inflation, and the short-term real interest rate. Note that in contrast to Figures 2 and 3, which showed deviation from the pre COVID-19 world, the results in these figures show the difference between the COVID-19 baseline and the cooperative outcome. We deliberately display the effects of the fiscal support separately: the blue line with the square symbol shows the impact of the fiscal support in A2 and E2 countries. In contrast with this, the orange line shows the full impact of the G20 cooperation process, namely the outcome showing both the effects of the fiscal support and the effects of the reduction in global risk. The differences between these lines show the contribution of the reduction in global risk to the full outcome.

Figures 4 and 5 shows the results for the US and Germany as representatives of group A1 countries. Consider first the effects of the fiscal support in the A2 and E2 countries. Remember that these countries are not themselves changing their fiscal support but are benefiting from the greater fiscal support undertaken in the countries in groups A2 and E2 which cooperation makes possible and from the reduction in global risk which $\mathrm{G} 20$ cooperation also makes possible.

In Figure 4, the effects on the US of the fiscal support in the A2 and E2 countries are exactly what we would expect. US activity and employment increase by a modest amount because of positive spillovers coming from an increase in exports; the trade balance improves by more than one per cent of GDP in 2020. Inflation increases, and interest rates are raised, and so both consumption and investment are held back. Despite all of this the dollar depreciates. That is because, as we describe below, the currencies of the E2 countries appreciate significantly. (The particular outcomes for Italy, which is 
within the Eurozone, are discussed below.) The results for Germany shown in Figure 5 are very similar but much larger than for the United States. That is both because Germany is more exposed to trade than the United States, and also because both Italy and other countries in the Eurozone are expanding. The fact that monetary policy in the Eurozone is made by the European Central Bank means that interest rates do not rise as much as they would do if Germany were operating its own currency, even though interest rates rise across Europe by quite a lot more than they do in the United States.

Now consider the effects on the United States and Germany of a reduction in global risk. We can see that in both countries there is a very significant stimulus to investment, something which lasts into the medium term and extends well beyond the 6 years shown in these pictures. The effect of this stimulus to investment is dampened in the first couple of years by the very significant rise in short-term interest rates in response to the very significant pick-up in inflation. Note that relative to the non-COVID-19 projections this means that interest rates do not fall as much as in the COVID-19 baseline. Despite such contractionary monetary policy, the real exchange rate depreciates significantly, because of the appreciation of the exchange rates in the A2 and E2 countries which we discuss below.

Figure 6 shows the results for Italy. The effect is a huge stimulus to consumption and investment and, as already noted, a very significant short-term increase in the level in GDP and employment. There is a huge increase in inflation (or less deflation compared to the pre-COVID-19 projections) because Italian authorities are not able to increase the normal interest rate enough to moderate this increase, as a result of Italy being a member of the European Monetary Union. This inflationary pressure makes Italy very uncompetitive from year 2 onwards, creating a very large increase in unemployment which takes a long time to remove. The effect of the removal of global risk is to stimulate investment in a way which continues into the future for a number of years: investment in Italy is at least 2 per cent higher than it would otherwise have been without this global risk reduction. These pictures for Italy indicate, yet again, the adjustment difficulties created for a country by not having control of its own monetary policy when asymmetric shocks happen. Nevertheless, compared to Figure 2 it is clear that the outcome for Italy of the global cooperation process is a very definite dampening of the COVID-19 shock.

Figure 7 shows the results for China. Recall that China is not increasing fiscal support. The effects on China of the fiscal support by the A2 and E2 countries is very similar to that in the United States. China experiences positive spill-overs, through trade, coming from the countries which are expanding, and the effect of this is dampened by an increase in the interest rate. Where China differs somewhat from the United States is the consequences of a reduction in global risk. One might have expected this to have a much bigger effect in China, but that is not the case. The reason for this is the worsening competitiveness of the Chinese economy relative to other Asian economies as the fall in risk is larger for China relative to its major competitors such as Japan, South Korea, and the Rest of Asia. Thus the Chinese real exchange rate appreciates relative to other Asian economies despite the crawling peg relative to the US dollar. 
Figure 4: Results for USA
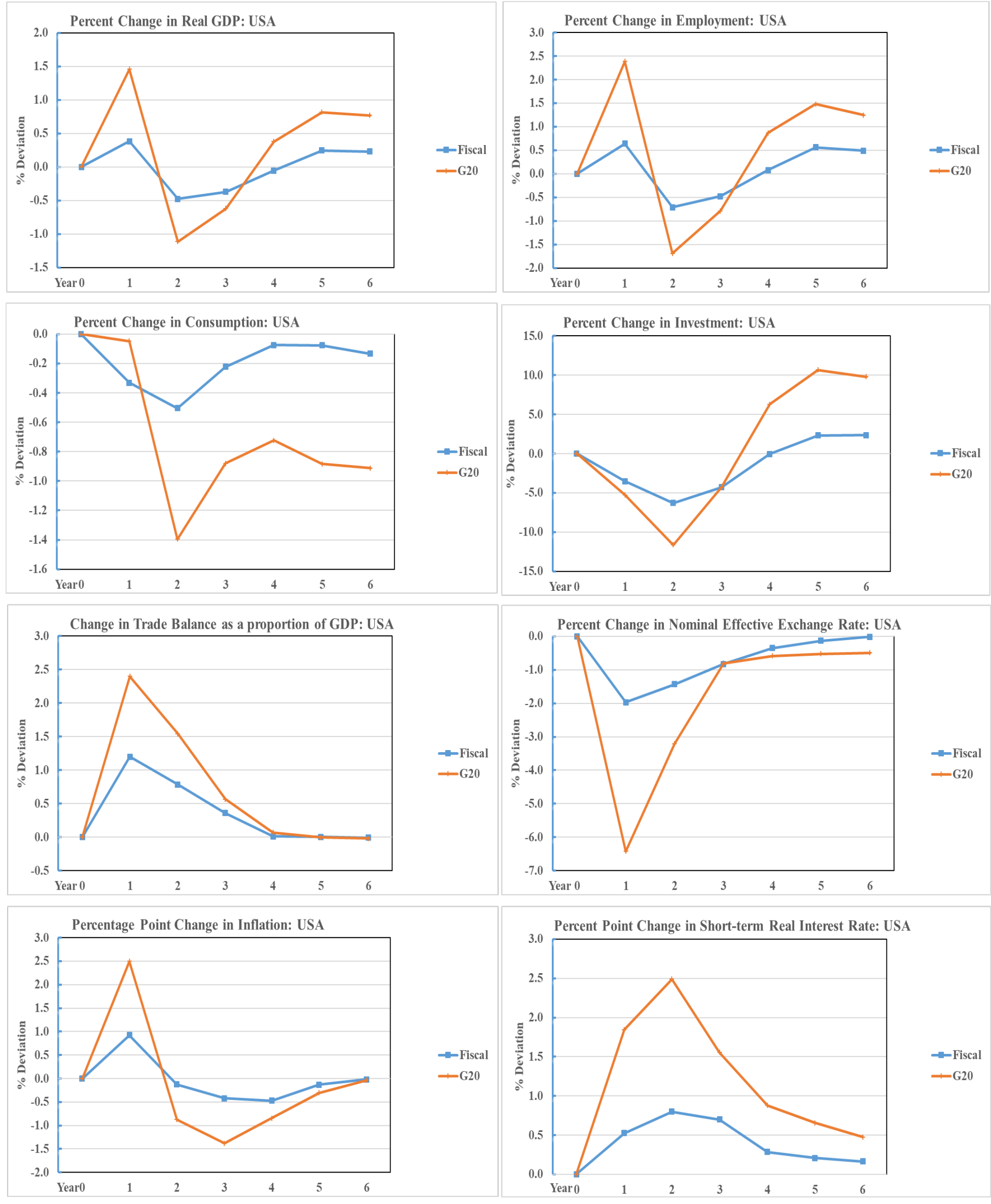
Figure 5: Results for Germany
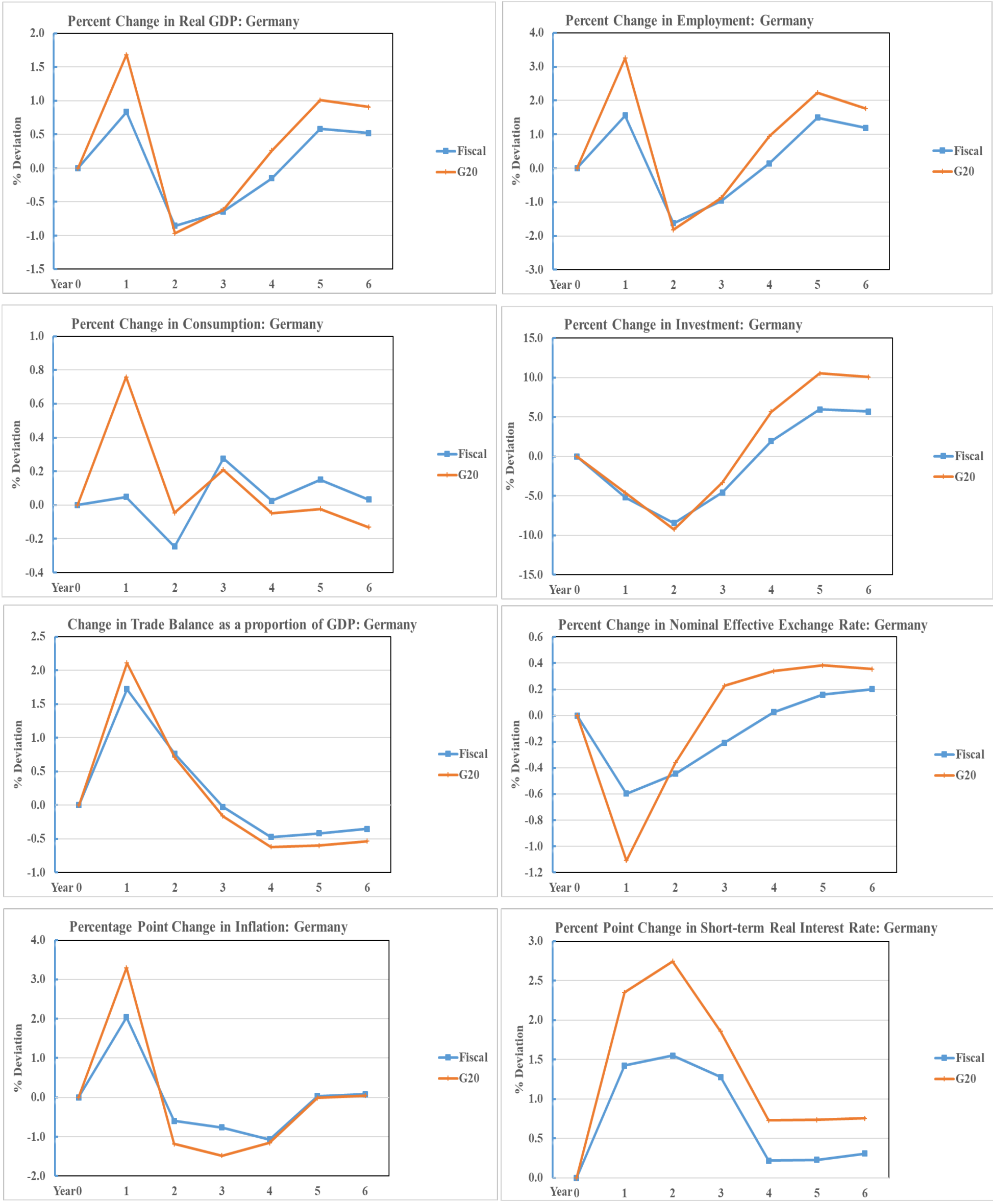
Figure 6: Results for Italy
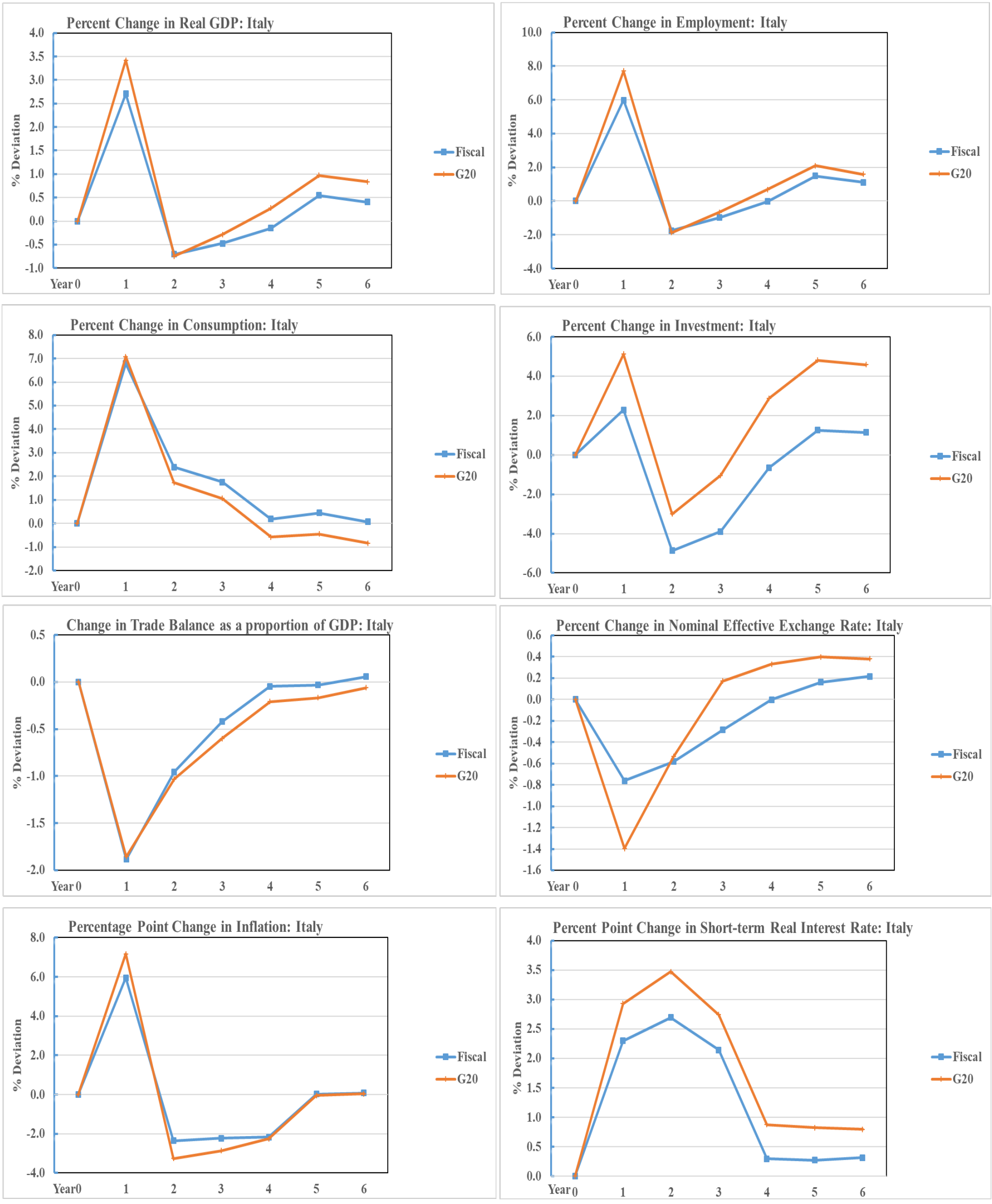
Figure 7: Results for China
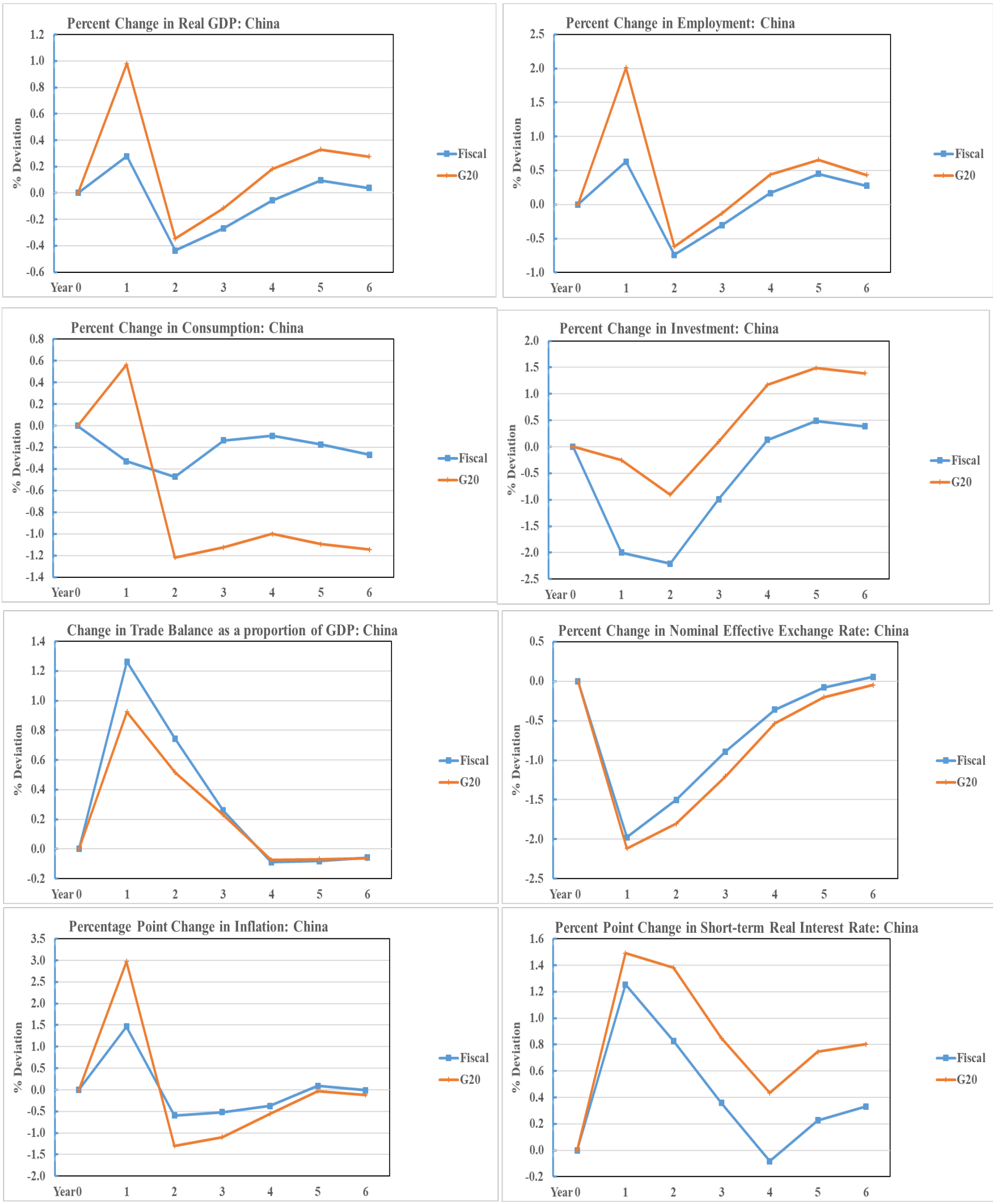
Figure 8: Results for Indonesia
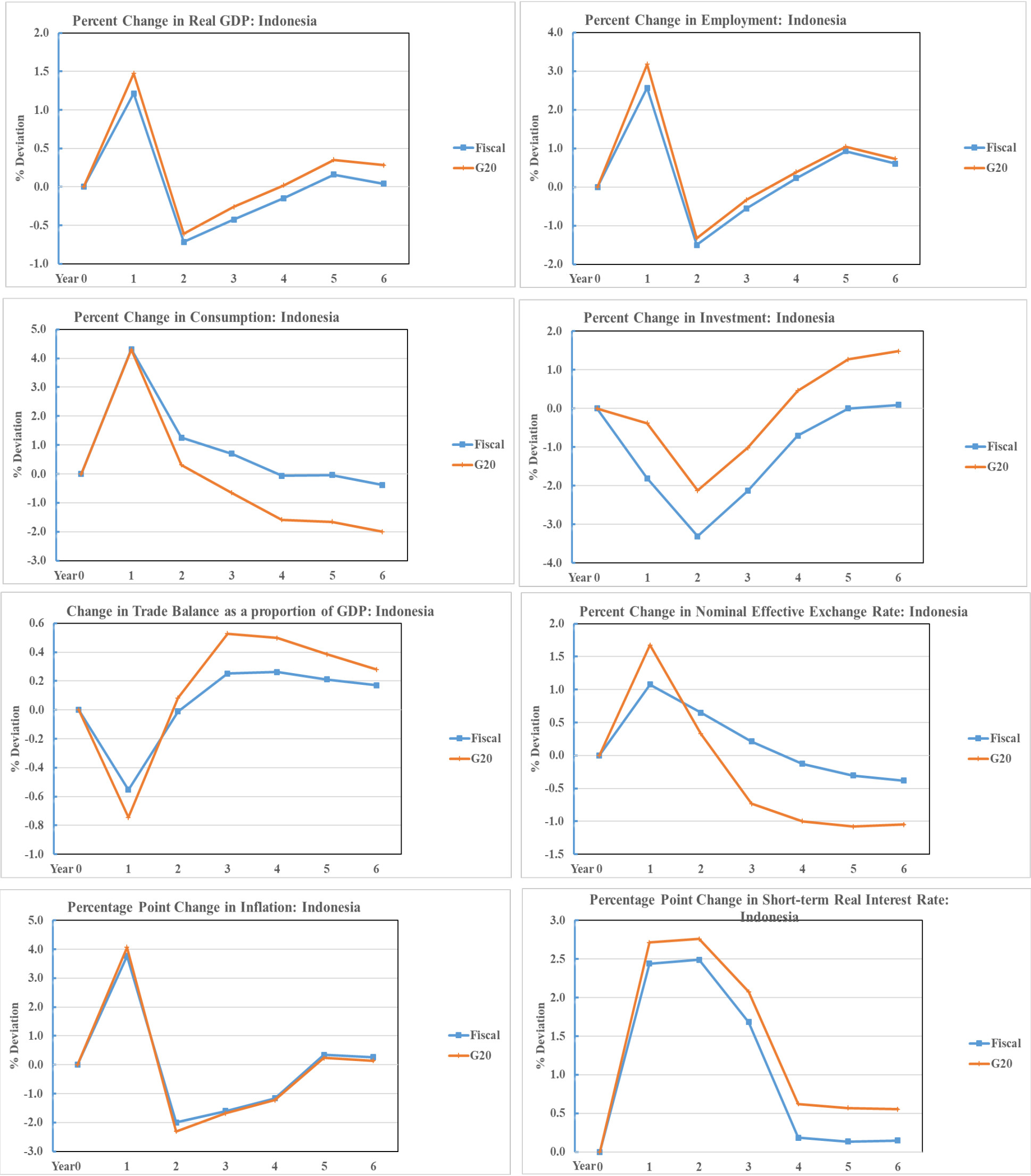
Figure 8, showing the results for Indonesia, is perhaps the most interesting figure. It shows that the policy of international cooperation can dampen the fall in GDP caused in Indonesia by the COVID-19 crisis, by more than 2 per cent of GDP. The fact that this policy does not have a larger effect is somewhat surprising since the extra fiscal support has been as large as 6 per cent of GDP. The reason for this is that real interest rates are increased significantly, dampening the effects of the shock. Of course interest rates are still lower than they would be in the pre-COVID-19 projections, but they no longer drop as sharply as in the Baseline Scenario. The effect of this policy is to stimulate employment by a much larger amount than the stimulus to GDP. There are two reasons for this. First, the fiscal expansion means that inflation is larger than it would have been with nominal wage rigidity real wages and productivity both fall, meaning that employment rises by more than output. The second effect is a commodity composition effect; increased consumer expenditure means that the proportion of total demand directed towards services sector output rises; since services are more labour intensive than other sectors, the percentage rise in employment will be greater than the percentage rise in output.

Notice how, for many of these countries, the boost to investment is both large and long lasting. The reduction in global risk plays an important role here; the long-lasting reduction in the equity risk premium has a very long-lasting effect on investment. Since this is a reduction in global interest rates, investment remains high not just in those countries in which there is extra fiscal support.

\section{(iii) Additional important aspects of the results}

It is useful to return to Tables 4-7 and use them to articulate some additional important features of our results.

First, Tables 4 and 5 enable us to understand more about the changes in fiscal deficits which emerge as a result of the increase in fiscal support which we are examining. It is apparent from Table 4 that the quantitative implications for the fiscal deficit of the enhanced fiscal support differ greatly as between the different countries undertaking this enhanced fiscal support, with the fiscal deficit numbers in India and Brazil being much larger than those in other countries. But Table 5 reveals that these differences come about almost entirely because of differences in the size of the countries in which the fiscal action is being undertaken. In almost all of the countries where enhanced fiscal support is undertaken, the ex post fiscal deficit in 2020 is nearly 6 per cent of GDP, nearly as large as the reduction in lump-sum taxes. But it is not quite as large; this is because the extra fiscal support stimulates economic activity which, because of the operation of automatic stabilizers, makes tax revenues rise, so reducing the size of the ex post fiscal deficit. In the countries where extra fiscal support is not being provided, international spillovers through trade mean that the fiscal position improves as a result of the higher tax revenues which follow on from a higher level of activity. But the improvement is not large; it is much less than 1 per cent of GDP.

Table 4 also shows, as expected, that the fiscal position in the countries in which there is no extra fiscal support, improves in the first year, simply because foreign spillovers coming through international trade lead to higher activity and thus to higher tax revenues. But in the second year the fiscal position of these countries worsens, particularly in the US, but the same effect can be seen at work in the United Kingdom, France, and China. This might seem surprising given that the fiscal support is smaller in 
year 2 (4 per cent of GDP) than in year 1 ( 6 per cent of GDP). What is happening is that, in the A2 and E2 countries in which there is increased fiscal support, returns on equity increase, and capital is attracted to them from the A1 and E1 countries where this is not happening. Productive potential, output, and thus tax revenues, increase in the first set of countries. Similarly by 2021, productive potential, output, and tax revenues fall in the second group of countries, namely the US, the UK, France, China, and other A1 countries. This supply-side effect is an important part of how international transmission happens in the G-cubed (G20) model.

Turn now to Table 6 which shows that the trade balance worsens much more in some of the countries providing fiscal support than in others. For example, the deterioration in the trade balance in South Africa is 5.5 per cent of GDP, in India it is 3.3 per cent of GDP, whereas in other countries it is only 1 or 2 per cent of GDP. These differences arise from the different risk premia which the model's calibration shows the COVID-19 crisis has caused in the different countries, with South Africa having the biggest risk premium, followed by India, Brazil, and Indonesia, in that order. In the first 2 years, the process of G20 cooperation is supposed to remove half of the household risk, and half of the currency risk, and to remove half of the equity risk premium in the first 2 years and to remove it completely going into the future. It is no surprise that the countries with the biggest risk premia expand more when some part of this risk premium is removed by the process of international cooperation, and that these countries experience a bigger worsening of the trade balance as a result.

The last interesting thing which we can learn from the tables comes from comparing Table 6 with Table 7. Table 6 shows that the trade deficit worsens in all the countries in which fiscal support is increasing. But Table 7 shows that the current account surplus of, in particular, Brazil actually improves by a very large amount, even in the first year. The final column in Table 7 shows that not just Brazil, but many other countries as well, end up with an improved external position, even after increased fiscal support has caused output to rise and the trade balance to worsen. The reason for this is interest rate effects and valuation effects. As already noted, Brazil has a considerable amount of foreign debt, so that when global interest rates come down, the interest obligations on this debt are reduced, improving the current account. Furthermore, much of the foreign borrowing is denominated in US dollars ('original sin') meaning that the improvement in the real exchange rate coming from the reduction in risk premium attached to Brazil, means that the burden of this debt actually diminishes.

\section{Conclusions}

What to hope for going forward?

The COVID-19 crisis has caused the greatest collapse in global economic activity since 1720 . Some advanced countries have mounted a massive fiscal response, both to pay for disease-fighting action and to preserve the incomes of firms and workers until the economic recovery is under way. But there are many emerging market economies which have been prevented from doing that by their high existing levels of public debt and - especially — by the external financial constraints which they face.

We have argued in the present paper that there is a need for international cooperation to allow such countries to undertake the kind of massive fiscal response that all countries now need, and that many advanced countries have been able to carry out. We have set out in detail what such cooperation might 
involve. And we have used the G-Cubed (G20) global macroeconomic model to explore how exceptionally beneficial such cooperation might be. Our simulations of the model have suggested that GDP in the countries in which extra fiscal support takes place might be around two and a half per cent higher in the first year, and that GDP in other countries in the world might be more than one per cent higher. And the percentage increase in employment in the countries undertaking the extra fiscal support might be much larger than the outcomes for GDP.

The necessary cooperation will need to be led by the Group of Twenty (G20), just as happened in 2008-9, since the G20 brings together the leaders of the world's largest economies. In this paper we have not gone into any of the details of what fiscal support might actually involve, we have actually just simulated large cuts in lump-sum taxes. Nor have we talked in any detail about how the cooperative process might be managed, except to suggest that a process of 'concerted unilateralism' might be valuable.

But let us now briefly ask, what exactly might such a process of cooperation actually involve?

As already noted in the paper, there is a lesson to be learned here from the time, in 2014, when Australia was in the G20 Chair. Australian officials were determined to impose a mechanism of delivery, rather than to allow the G20 process to continue to drift. They set about a process which led to the '2-in-5' agreement at the Heads of Government meeting in Brisbane in November 2014: a list of policies to which global leaders were committed, designed to increase global growth by 2 per cent over a period of 5 years. As we have already noted, subsequent reviews judged this policy agreement to have been at least partially successful in influencing global macroeconomic outcomes.

Just as in 2014, the first stage in any such cooperative process would be to obtain global agreement that an increase fiscal support of the kind examined in this paper is both necessary and possible. This is the kind of agreement that was hammered out in the run-up to the London G20 summit in 2009. A similar kind of agreement was reached in the early months of 2014 when Australia chaired the G20. The second stage in any such corporative process would be an agreement as to who actually does what.

The reason why the G20 was able to be effective, both in 2008-9 and, less obviously, in 2014, has lessons for what might be done now. As a preliminary process, leaders might be asked to agree on focus: to agree about what it is that countries are trying to achieve. The kind of fiscal support which we have examined in this paper might well be something on which leaders might agree to focus their attention. In 2014, when Australia chaired the G20, the objective was to raise the global growth rate by 2 per cent over a period of 5 years. Here the objective might well be to raise GDP by 2 per cent in countries which are constrained by not being able to expand and to achieve this kind of outcome in much less than 5 years, the kind of outcomes which we have explored in our simulations of the GCubed (G20) model. To this end, countries might be invited to propose policies which each might embark upon on, so as to contribute to this overall process of fiscal support, in pursuit of a higher level of global activity. Second, each country's proposals might be reviewed by another country to see if what had been proposed was 'fair' in the sense of making an adequate contribution to the overall objective of providing fiscal support. If necessary (and this happened in 2014), countries would then be invited to 'do a bit more', so that the whole thing would add up to being big enough. What would be essential in this process is that there would not be a process of top-down instruction, or top-down enforcement of the kind of conditionality that is a central part of the operation of IMF Programmes. 
Such international cooperation must also, necessarily, involve a promise of international financial support from the IMF. Otherwise, as we have already argued, international financial markets might take fright at the large budget deficits and current account deficits which would emerge, and might create fiscal crises and currency crises, thereby bringing to an end the policies of fiscal support which were being undertaken. A great many details would need to be ironed out; things which we have deliberately not discussed in this paper. These will need to include:

(i) large IMF programmes for a number of countries;

(ii) global liquidity management through swaps coordinated by the Federal Reserve, the Bank of England, the ECB, the Bank of Japan, and the Bank of China;

(iii) provision of funding for Italy, and for other peripheral states in the Eurozone, beyond what is now allowed within the rules of the European Monetary Union;

(iv) debt relief for poorest countries and emerging market economies along the lines recently agreed by the G20 (see Bery and Brekelmans (2020)); and

(v) the additional proposal put forward recently by the CEPR for debt relief for the poorest countries (see https://cepr.org/content/new-cepr-policy-insight-born-out-necessity-debtstandstill-COVID-19).

More generally there would need to be an undertaking that the IMF would be prepared to do 'whatever it takes' to ensure global financial stability in case the difficulties in the way of the policy proposed here turn out to be greater than those which we have captured in the modelling work reported in this paper.

This is actually an extraordinary plan, but these really are extraordinary times. The last time the world faced challenges as serious as those we now face was at the end of the Second World War. At that time there was a breathtaking burst of institutional creativity. In particular, the Bretton Woods Conference in 1944 led to the creation of the IMF, in order to ensure the kind of international financial stability which would be fundamental if a plan like that described here were to be actually carried out. The Bretton Woods Conference also led to the establishment of the World Bank as an institution which would lend money to what were then the emerging market economies, at that time in Europe and Asia. Soon afterwards the Marshall plan also started to provide money for countries in need.

These post-Second World War institutions - particularly the Fund and the Bank- have served the world remarkably well. They still provide a framework within which international cooperation can take place. Now, following the COVID-19 pandemic, these institutions need strengthening and reinvigorating. The necessary work of reconstruction has already begun in that, after the GFC, the G20 was given such an important role - even if in subsequent years it managed to somehow lose its way. Even the G20 — not much more than 10 years old — needs reinvigoration.

Because the pandemic is such a very large event we need to realize that the world faces a very large choice. We can do what the world did in the late 1940s, when it chose to establish institutions which helped to guide world economy through the golden age of global growth during the 1950s and 1960s. Or we can instead allow what happened in the 1930s to happen all over again. We think that the policies of fiscal support put forward in this paper are one part of what is needed for the world to make a good choice rather than a bad choice. 


\section{Appendix}

Figure A1: Labour force shocks in the Baseline Scenario

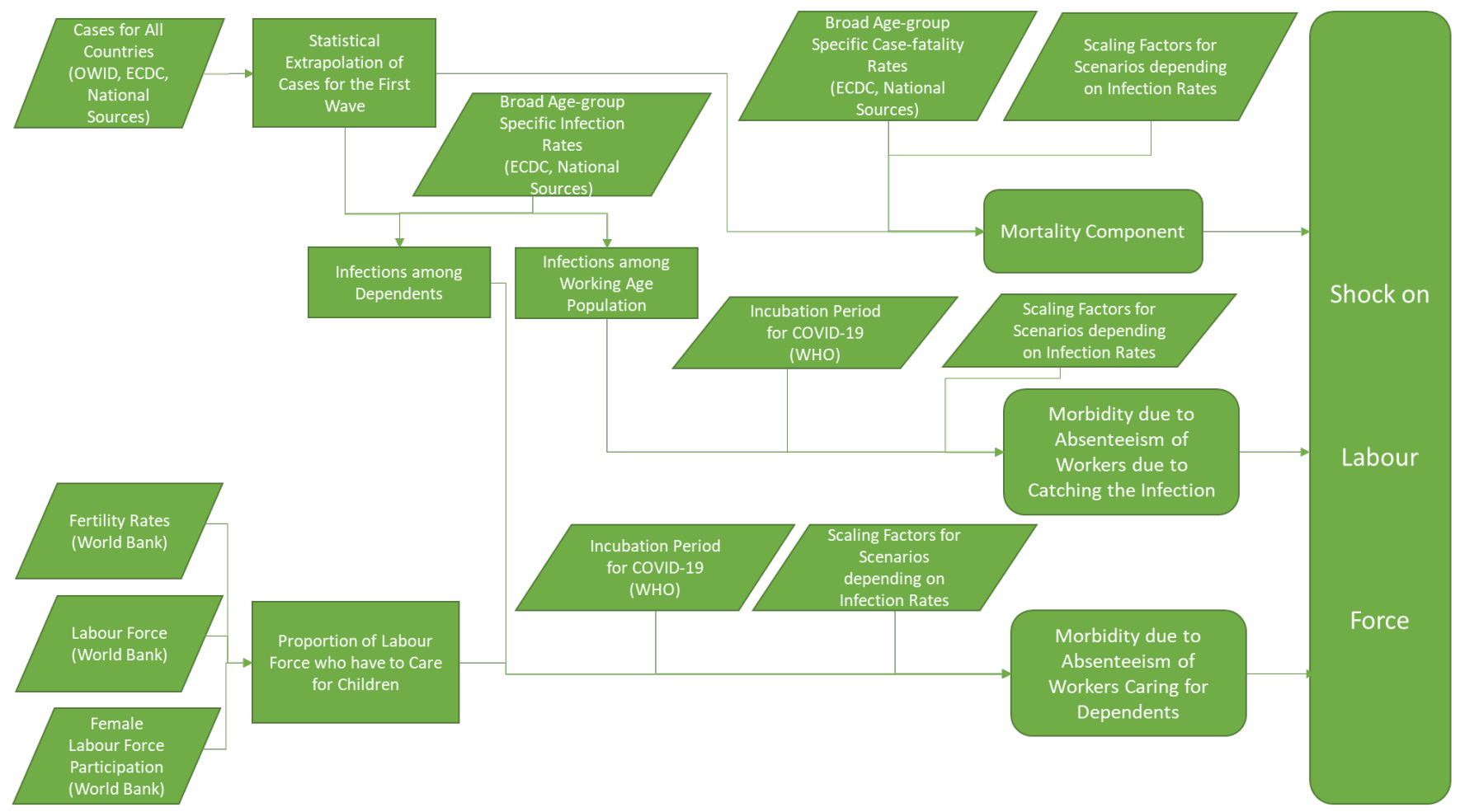

Source: McKibbin and Fernando (2020b). 
Figure A2: Shocks to consumption in the Baseline Scenario

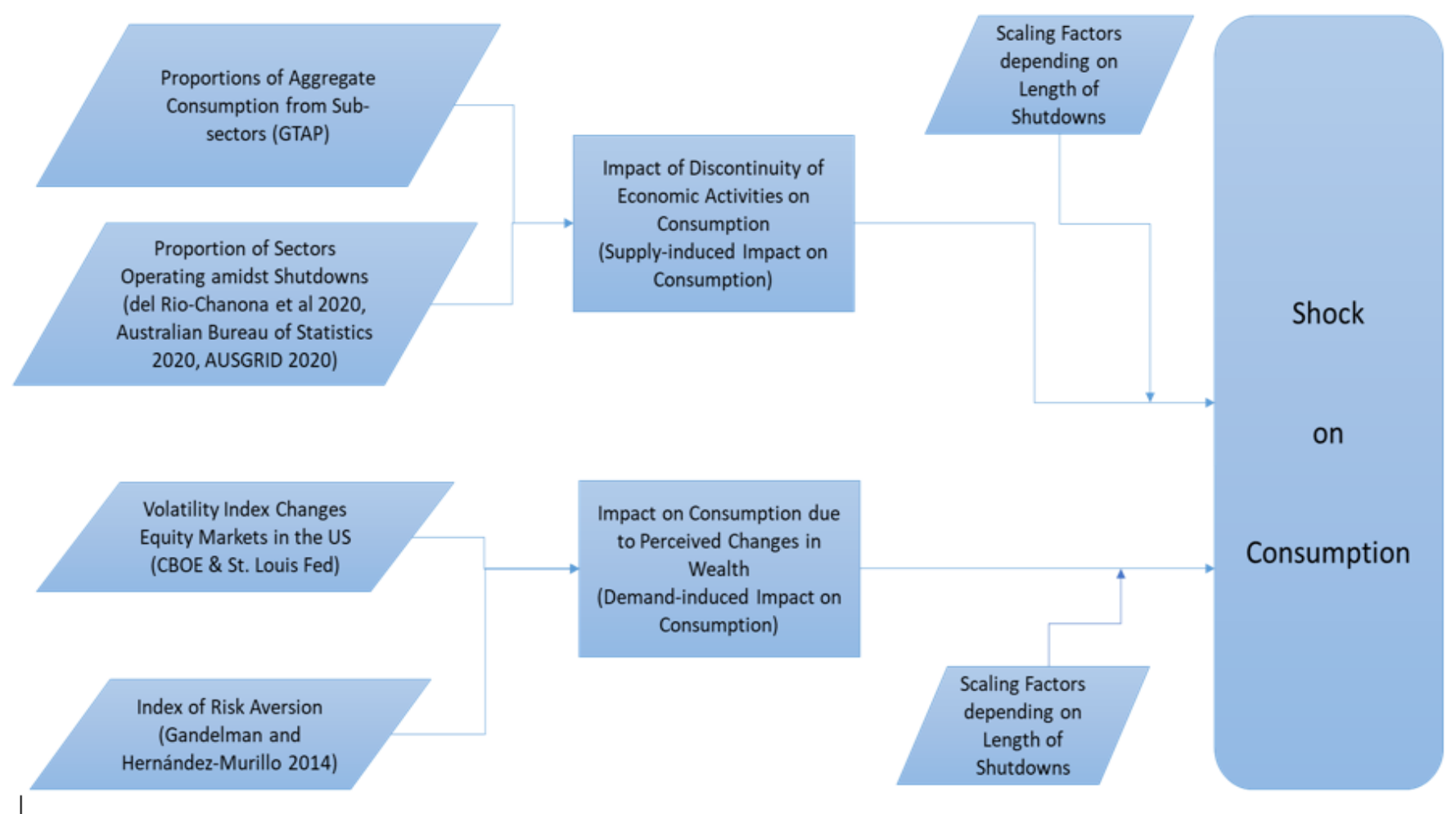

Source: McKibbin and Fernando (2020b).

Figure A3: Shocks to productivity and equity risk premium in the Baseline Scenario

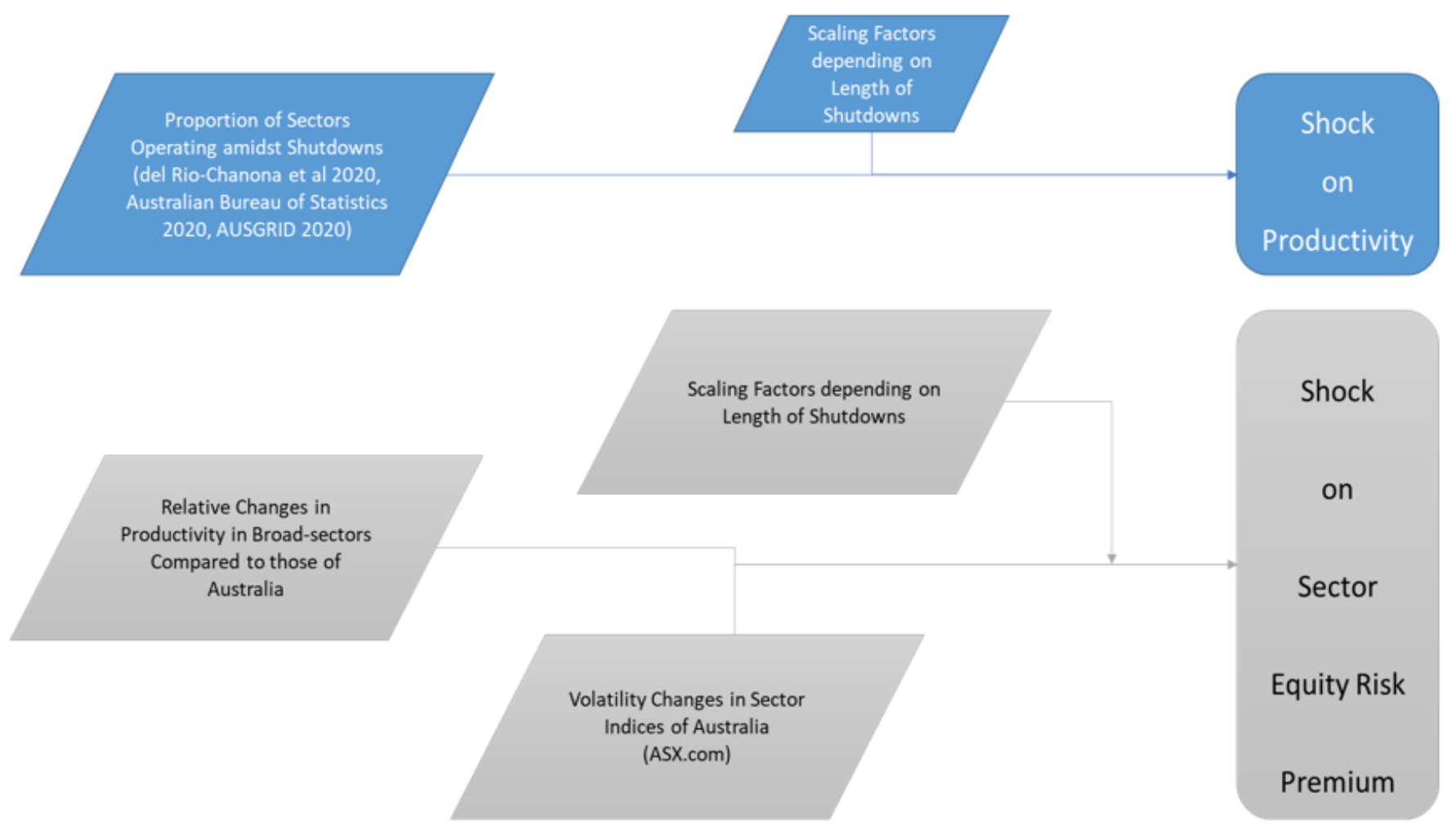

Source: McKibbin and Fernando (2020b). 
Figure A4: Shocks to country risk in the Baseline Scenario

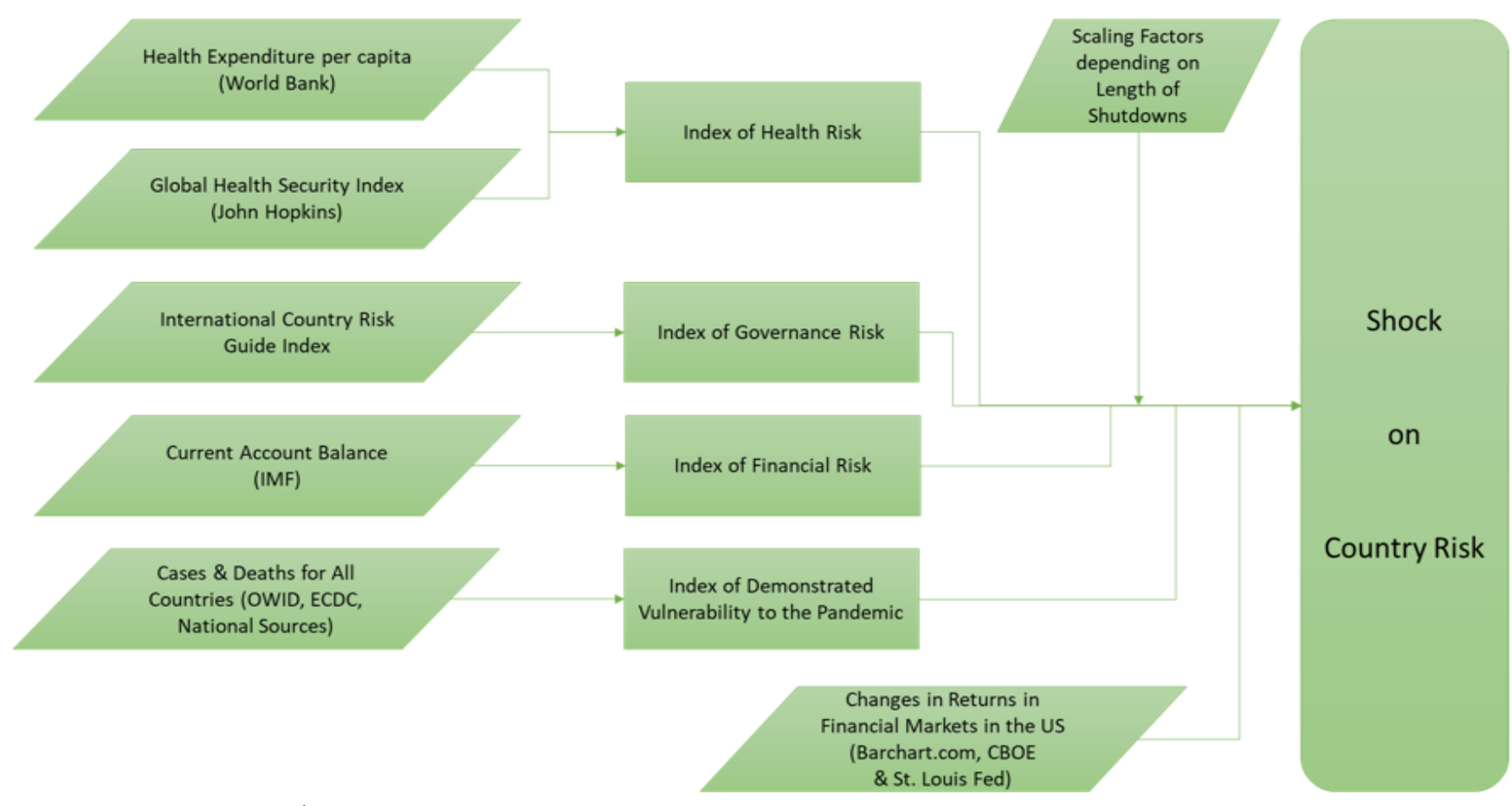

Source: McKibbin and Fernando (2020b).

Figure A5: Fiscal policy responses in the Baseline Scenario

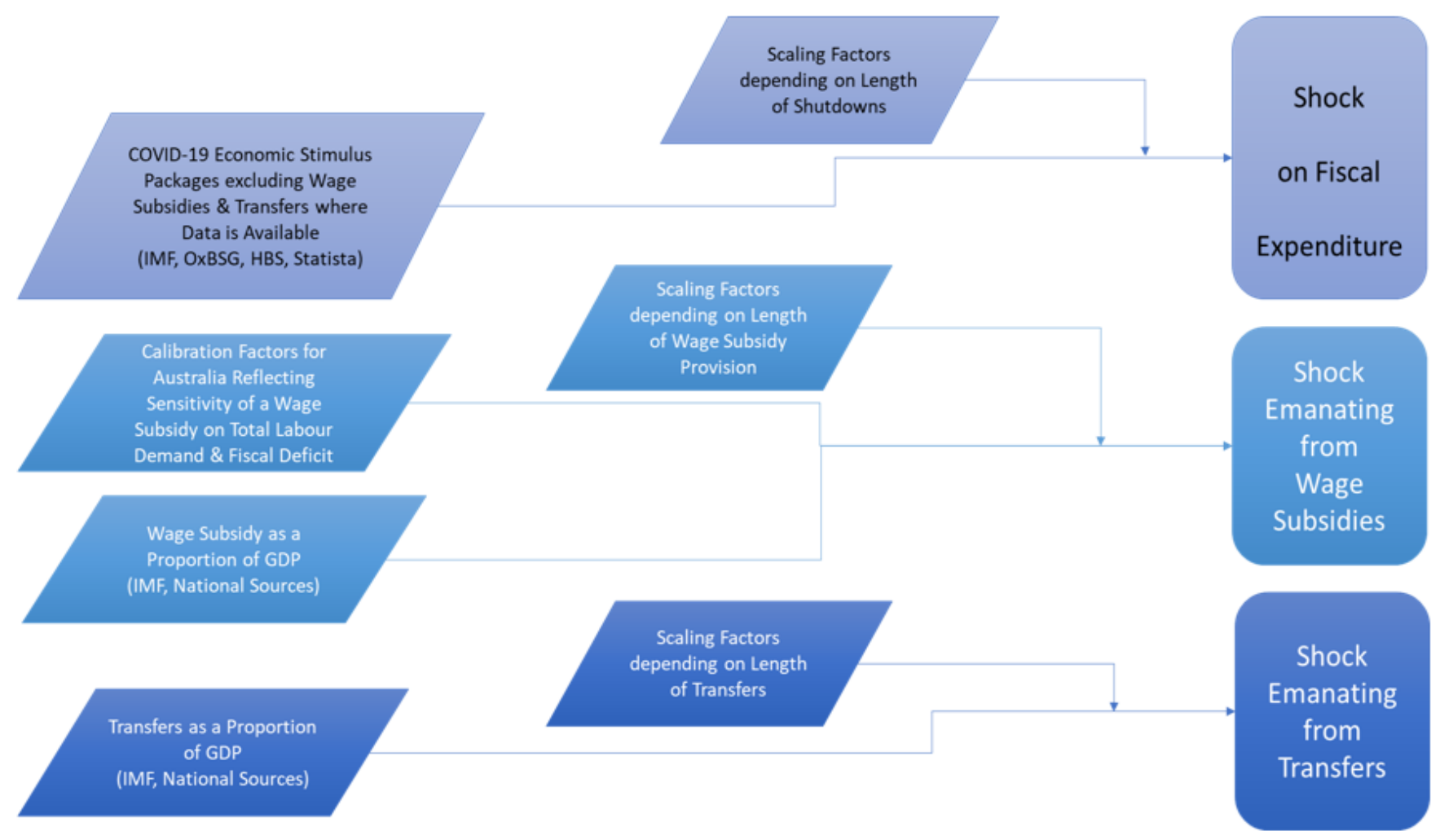

Source: McKibbin and Fernando (2020b). 
Table A1: Shocks to household and country risk premia in the Baseline Scenario

\begin{tabular}{|c|c|c|c|c|c|c|}
\hline \multirow{2}{*}{ Country/Region } & \multicolumn{3}{|c|}{ Human Capital Risk } & \multicolumn{3}{|c|}{ Country Risk relative to USA } \\
\hline & 2020 & 2021 & 2022 & 2020 & 2021 & 2022 \\
\hline USA & 5.66 & 4.00 & 0 & 0 & 0 & 0 \\
\hline Japan & 1.50 & 1.06 & 0 & 4.73 & 3.35 & 0 \\
\hline Germany & 2.59 & 1.83 & 0 & 4.19 & 2.96 & 0 \\
\hline United Kingdom & 3.92 & 2.77 & 0 & 6.88 & 4.86 & 0 \\
\hline France & 4.88 & 3.45 & 0 & 5.60 & 3.96 & 0 \\
\hline Italy & 2.78 & 1.97 & 0 & 5.50 & 3.89 & 0 \\
\hline Rest of Euro Zone & 2.81 & 1.99 & 0 & 5.64 & 3.99 & 0 \\
\hline Canada & 3.16 & 2.23 & 0 & 6.16 & 4.35 & 0 \\
\hline Australia & 4.17 & 2.95 & 0 & 5.70 & 4.03 & 0 \\
\hline Rest of OECD & 4.08 & 2.89 & 0 & 5.06 & 3.58 & 0 \\
\hline South Korea & 0.82 & 0.58 & 0 & 4.38 & 3.10 & 0 \\
\hline Turkey & 2.31 & 1.63 & 0 & 6.93 & 4.90 & 0 \\
\hline China & 6.02 & 4.26 & 0 & 6.61 & 4.67 & 0 \\
\hline India & 3.82 & 2.70 & 0 & 8.63 & 6.10 & 0 \\
\hline Indonesia & 4.29 & 3.03 & 0 & 7.78 & 5.50 & 0 \\
\hline Other Asia & 7.50 & 5.31 & 0 & 6.15 & 4.35 & 0 \\
\hline Mexico & 2.88 & 2.04 & 0 & 7.48 & 5.29 & 0 \\
\hline Argentina & 4.45 & 3.15 & 0 & 8.94 & 6.32 & 0 \\
\hline Brazil & 2.60 & 1.84 & 0 & 7.83 & 5.54 & 0 \\
\hline Russia & 2.52 & 1.78 & 0 & 6.97 & 4.93 & 0 \\
\hline Saudi Arabia & 6.22 & 4.40 & 0 & 5.54 & 3.92 & 0 \\
\hline South Africa & 6.43 & 4.54 & 0 & 10.81 & 7.64 & 0 \\
\hline Rest of World & 4.05 & 2.86 & 0 & 11.21 & 7.93 & 0 \\
\hline Rest of OPEC & 7.67 & 5.42 & 0 & 8.95 & 6.33 & 0 \\
\hline
\end{tabular}

Source: McKibbin and Fernando (2020b)

Table A1 and Table A2 together contain the details of the risk shocks which are part of the information which was used to create the baseline simulation. The three shocks that are designed to capture the higher risk as a result of COVID-19 are (i) an increase in the household risk premium, (ii) an increase in the country risk premium, and (iii) an increase in the equity risk premium. These risk shocks vary across countries and are calibrated to the scale of the epidemiological shocks across all countries in year 1. In year 2, in the baseline simulation, this COVID-19 risk premium follows the pattern of the epidemiological assumptions - falling by a factor of half across all three kinds of risk premia, across all countries. In year 3 this COVID-19 risk premium is assumed to disappear, both in the case of country risk premia and household risk premia. But in the case of the equity risk premium, it is assumed to stay the same as it is in year 2 - an amount equal to half the original amount - for all years into the future. This captures the assumption that the virus is never eliminated.

The entries in the Table A1 above show the values of the human capital risk and the household risk for each country in 2020 and 21 . Table A2 shows the values of the equity risk premium for each country for 2020 and 2021; entries for 2022 and beyond are the same as in 2021. But now, of course, this requires six entries per country per year, one for each industry. 
Table A2: Shocks to equity risk premia in the Baseline Scenario

\begin{tabular}{|c|c|c|c|c|c|c|c|c|c|}
\hline \multirow{2}{*}{$\begin{array}{l}\text { Country/ } \\
\text { Region }\end{array}$} & \multicolumn{3}{|c|}{ Energy } & \multicolumn{3}{|c|}{ Mining } & \multicolumn{3}{|c|}{ Agriculture } \\
\hline & 2020 & 2021 & 2022 & 2020 & 2021 & 2022 & 2020 & 2021 & 2022 \\
\hline USA & 2.32 & 1.64 & 1.64 & 2.85 & 2.02 & 2.02 & 2.17 & 1.53 & 1.53 \\
\hline Japan & 1.37 & 0.97 & 0.97 & 1.68 & 1.19 & 1.19 & 1.28 & 0.90 & 0.90 \\
\hline Germany & 1.30 & 0.92 & 0.92 & 1.60 & 1.13 & 1.13 & 1.22 & 0.86 & 0.86 \\
\hline $\begin{array}{l}\text { United } \\
\text { Kingdom }\end{array}$ & 1.89 & 1.34 & 1.34 & 2.32 & 1.64 & 1.64 & 1.76 & 1.25 & 1.25 \\
\hline France & 1.37 & 0.97 & 0.97 & 1.68 & 1.19 & 1.19 & 1.28 & 0.90 & 0.90 \\
\hline Italy & 1.57 & 1.11 & 1.11 & 1.93 & 1.37 & 1.37 & 1.47 & 1.04 & 1.04 \\
\hline $\begin{array}{l}\text { Rest of Euro } \\
\text { Zone }\end{array}$ & 1.62 & 1.14 & 1.14 & 1.99 & 1.40 & 1.40 & 1.51 & 1.07 & 1.07 \\
\hline Canada & 1.89 & 1.34 & 1.34 & 2.32 & 1.64 & 1.64 & 1.76 & 1.25 & 1.25 \\
\hline Australia & 1.56 & 1.10 & 1.10 & 1.92 & 1.36 & 1.36 & 1.46 & 1.03 & 1.03 \\
\hline Rest of OECD & 1.49 & 1.05 & 1.05 & 1.83 & 1.30 & 1.30 & 1.39 & 0.98 & 0.98 \\
\hline South Korea & 0.97 & 0.68 & 0.68 & 1.19 & 0.84 & 0.84 & 0.90 & 0.64 & 0.64 \\
\hline Turkey & 0.89 & 0.63 & 0.63 & 1.10 & 0.78 & 0.78 & 0.83 & 0.59 & 0.59 \\
\hline China & 1.20 & 0.85 & 0.85 & 1.47 & 1.04 & 1.04 & 1.12 & 0.79 & 0.79 \\
\hline India & 2.47 & 1.74 & 1.74 & 3.03 & 2.14 & 2.14 & 2.30 & 1.63 & 1.63 \\
\hline Indonesia & 1.42 & 1.01 & 1.01 & 1.75 & 1.24 & 1.24 & 1.33 & 0.94 & 0.94 \\
\hline Other Asia & 2.32 & 1.64 & 1.64 & 2.85 & 2.02 & 2.02 & 2.17 & 1.53 & 1.53 \\
\hline Mexico & 1.73 & 1.22 & 1.22 & 2.13 & 1.50 & 1.50 & 1.61 & 1.14 & 1.14 \\
\hline Argentina & 1.76 & 1.24 & 1.24 & 2.16 & 1.53 & 1.53 & 1.64 & 1.16 & 1.16 \\
\hline Brazil & 2.42 & 1.71 & 1.71 & 2.97 & 2.10 & 2.10 & 2.26 & 1.59 & 1.59 \\
\hline Russia & 2.00 & 1.41 & 1.41 & 2.45 & 1.73 & 1.73 & 1.86 & 1.32 & 1.32 \\
\hline Saudi Arabia & 1.59 & 1.12 & 1.12 & 1.95 & 1.38 & 1.38 & 1.48 & 1.05 & 1.05 \\
\hline South Africa & 4.25 & 3.01 & 3.01 & 5.23 & 3.70 & 3.70 & 3.97 & 2.81 & 2.81 \\
\hline Rest of World & 2.83 & 2.00 & 2.00 & 3.48 & 2.46 & 2.46 & 2.64 & 1.87 & 1.87 \\
\hline Rest of OPEC & 2.97 & 2.10 & 2.10 & 3.65 & 2.58 & 2.58 & 2.77 & 1.96 & 1.96 \\
\hline
\end{tabular}

Source: McKibbin and Fernando (2020b)

Table A2 (continued): Shocks to equity risk premia in the Baseline Scenario

\begin{tabular}{|c|c|c|c|c|c|c|c|c|c|}
\hline \multirow{2}{*}{ Country/Region } & \multicolumn{3}{|c|}{ Durable Manufacturing } & \multicolumn{3}{|c|}{ Non-durable Manufacturing } & \multicolumn{3}{|c|}{ Services } \\
\hline & 2020 & 2021 & 2022 & 2020 & 2021 & 2022 & 2020 & 2021 & 2022 \\
\hline USA & 2.02 & 1.43 & 1.43 & 2.08 & 1.47 & 1.47 & 2.39 & 1.69 & 1.69 \\
\hline Japan & 1.19 & 0.84 & 0.84 & 1.22 & 0.87 & 0.87 & 1.41 & 0.99 & 0.99 \\
\hline Germany & 1.14 & 0.80 & 0.80 & 1.17 & 0.82 & 0.82 & 1.34 & 0.95 & 0.95 \\
\hline United Kingdom & 1.65 & 1.17 & 1.17 & 1.69 & 1.20 & 1.20 & 1.94 & 1.37 & 1.37 \\
\hline France & 1.19 & 0.84 & 0.84 & 1.22 & 0.87 & 0.87 & 1.41 & 0.99 & 0.99 \\
\hline Italy & 1.37 & 0.97 & 0.97 & 1.41 & 1.00 & 1.00 & 1.62 & 1.14 & 1.14 \\
\hline Rest of Euro Zone & 1.41 & 1.00 & 1.00 & 1.44 & 1.02 & 1.02 & 1.66 & 1.17 & 1.17 \\
\hline Canada & 1.65 & 1.17 & 1.17 & 1.69 & 1.20 & 1.20 & 1.94 & 1.37 & 1.37 \\
\hline Australia & 1.36 & 0.96 & 0.96 & 1.39 & 0.99 & 0.99 & 1.60 & 1.13 & 1.13 \\
\hline Rest of OECD & 1.30 & 0.92 & 0.92 & 1.33 & 0.94 & 0.94 & 1.53 & 1.08 & 1.08 \\
\hline South Korea & 0.84 & 0.60 & 0.60 & 0.86 & 0.61 & 0.61 & 0.99 & 0.70 & 0.70 \\
\hline Turkey & 0.78 & 0.55 & 0.55 & 0.80 & 0.57 & 0.57 & 0.92 & 0.65 & 0.65 \\
\hline China & 1.05 & 0.74 & 0.74 & 1.07 & 0.76 & 0.76 & 1.23 & 0.87 & 0.87 \\
\hline India & 2.15 & 1.52 & 1.52 & 2.21 & 1.56 & 1.56 & 2.53 & 1.79 & 1.79 \\
\hline Indonesia & 1.24 & 0.88 & 0.88 & 1.27 & 0.90 & 0.90 & 1.46 & 1.03 & 1.03 \\
\hline Other Asia & 2.02 & 1.43 & 1.43 & 2.08 & 1.47 & 1.47 & 2.39 & 1.69 & 1.69 \\
\hline Mexico & 1.51 & 1.07 & 1.07 & 1.55 & 1.09 & 1.09 & 1.78 & 1.26 & 1.26 \\
\hline Argentina & 1.53 & 1.08 & 1.08 & 1.57 & 1.11 & 1.11 & 1.81 & 1.28 & 1.28 \\
\hline Brazil & 2.11 & 1.49 & 1.49 & 2.16 & 1.53 & 1.53 & 2.48 & 1.76 & 1.76 \\
\hline Russia & 1.74 & 1.23 & 1.23 & 1.78 & 1.26 & 1.26 & 2.05 & 1.45 & 1.45 \\
\hline Saudi Arabia & 1.38 & 0.98 & 0.98 & 1.42 & 1.00 & 1.00 & 1.63 & 1.15 & 1.15 \\
\hline South Africa & 3.71 & 2.62 & 2.62 & 3.81 & 2.69 & 2.69 & 4.37 & 3.09 & 3.09 \\
\hline Rest of World & 2.47 & 1.75 & 1.75 & 2.53 & 1.79 & 1.79 & 2.91 & 2.06 & 2.06 \\
\hline Rest of OPEC & 2.59 & 1.83 & 1.83 & 2.65 & 1.88 & 1.88 & 3.05 & 2.16 & 2.16 \\
\hline
\end{tabular}

Source: McKibbin and Fernando (2020b) 


\section{References}

Adam, C., Henstridge, M., and Lee, S. (2020), 'After the Lockdown: Macroeconomic Adjustment to the COVID-19 Pandemic in Sub-Saharan Africa', Oxford Review of Economic Policy, 36 (Supplement).

Allsopp, C., and Vines, D. (2015), 'Monetary and Fiscal Policy in the Great Moderation and the Great Recession', Oxford Review of Economic Policy, 31(2), 134-67.

Bery, S., and Brekelmans, S. (2020), 'The Revived Centrality of the G20', Bruegel Blog Post, available at https://www.bruegel.org/2020/04/the-revived-centrality-of-the-g20/

Blanchard, O. (2018), 'On the Future of Macroeconomic Models', Oxford Review of Economic Policy, 34(1-2).

Broadberry, S. N., and van Leeuwen, B. (2010), 'British Economic Growth and the Business Cycle, 1700-1870: Annual Estimates’, CAGE Online Working Paper Series, 2010(20).

Buiter, W., and Marston, R. (eds) (1985), International Economic Policy Coordination, Cambridge, Cambridge University Press.

Christiano, L., Eichenbaum, M., and Evans, C. (2005), 'Nominal Rigidities and the Dynamic Effects of a Shock to Monetary Policy', Journal of Political Economy, 113(1), 1-45.

Currie, D., and Levine, P. (1985), 'Macroeconomic Policy Design in an Interdependent World', in Buiter and Marston (1985), 228-73.

Eichengreen, B. (1985), 'International Policy Coordination in Historical Perspective: A View From the Interwar Years', in Buiter and Marston (1985), 139-83. Garnaut, R. (1996), Open Regionalism and Trade Liberalisation: An Asia-Pacific Contribution to the World Trade System, Singapore, Institute of East Asian Studies

Guerrieri, V., Lorenzoni, G., Straub, L., and Werning, I. (2020), 'Macroeconomic Implications of COVID-19: Can Negative Supply Shocks Cause Demand Shortages?', available at https://economics.mit.edu/files/19351

Henderson, D. W., and McKibbin, W. (1993), 'A Comparison of Some Basic Monetary Policy Regimes for Open Economies: Implications of Different Degrees of Instrument Adjustment and Wage Persistence', Carnegie-Rochester Conference Series on Public Policy, 39(1), 221317.

IMF (2020a), World Economic Outlook April 2020: The Great Lockdown, Washington, DC, International Monetary Fund.

- (2020b), World Economic Outlook Update June 2020: A Crisis Like No Other, An Uncertain Recovery, Washington, DC, International Monetary Fund.

- $\quad(2020 c)$, 'Tracking the \$9 Trillion Global Fiscal Support to Fight COVID-19', IMF Blog, 20 May, Washington, DC, International Monetary Fund, available at https://blogs.imf.org/2020/05/20/tracking-the-9-trillion-global-fiscal-support-to-fightCOVID-19/, accessed on 17 June 2020.

Lee, J. W. (2020), 'A Coordinated Response to COVID-19', Project Syndicate, 25 March.

McKibbin, W. J. (1988), 'The Economics of International Policy Coordination', The Economic Record, 64(187), 241-53. 
- Fernando, R. (2020a), 'The Global Macroeconomic Impacts of COVID-19: Seven Scenarios', COVID Economics: Vetted and Real Time Papers, 10, London, Centre for Economic Policy Research, 116-56.

- _ (2020b), 'Global Macroeconomic Scenarios of the COVID-19 Pandemic', CAMA Working Paper 62/2020, Australian National University.

- Triggs, A. (2018), 'Modeling the G20', CAMA Working Paper 17/2018, Australian National University.

- Vines, D. (2000), 'Modelling Reality: The Need for Both Intertemporal Optimization and Stickiness in Models for Policy-making', Oxford Review of Economic Policy, 16(4), 106-37.

- Wilcoxen, P. (1999), 'The Theoretical and Empirical Structure of the G-Cubed Model', Economic Modelling, 16(1), 123-48.

- _ (2013), 'A Global Approach to Energy and the Environment: The G-cubed Model', ch. 17 in Handbook of CGE Modelling, North-Holland, 995-1068.

OECD (2020), 'The World Economy on a Tightrope', OECD Economic Outlook, June, available at http://www.oecd.org/economic-outlook/june-2020/

Oudiz, G., and Sachs, J. (1985), 'International Policy Coordination in Dynamic Macroeconomic Models', in Buiter and Marston (1985), 274-330.

Rei, C. (2020), 'Coronavirus May Cause the Biggest Slump since the South Sea Bubble', University of Warwick website, available at https://warwick.ac.uk/newsandevents/expertcomment/coronavirus_may_cause/, accessed on 21 June 2020.

Smets, F., and Wouters, R. (2007), 'Shocks and Frictions in US Business Cycles: A Bayesian DSGE Approach', American Economic Review, 97(3), 586-606.

Taylor, J. B. (1993), 'Discretion versus Policy Rules in Practice', Carnegie-Rochester Conference Series on Public Policy, 39, 195-214.

Temin, P., and Voth, H.-J. (2004), 'Riding the South Sea Bubble', American Economic Review, 94(5), $1654-68$.

Vines, D. (2015), 'Cooperation between Countries to Ensure Global Economic Growth: A Role for the G20?', Asia Pacific Journal of Economic Literature, 29(1), 1-24, originally presented as the Thirteenth Heinz Arndt Memorial Lecture at the Australian National University in September 2014.

- (2016), 'On Concerted Unilateralism: When Macroeconomic Policy Coordination Is Helpful and When It Is Not', ch. 2 in T. Bayoumi, S. Pickford, and P. Subacchi (eds), Managing Complexity: Economic Policy Cooperation after the Crisis, Washington, DC, Brookings Press, 17-48.

- Wills, S. (2018), 'The Rebuilding Macroeconomic Theory Project: An Analytical Assessment', Oxford Review of Economic Policy, 34(1-2).

World Bank (2020), Global Economic Prospects June 2020, Washington, DC, World Bank Group, https://www.worldbank.org/en/publication/global-economic-prospects

Wren-Lewis, S. (2018), 'Ending the Microfoundations Hegemony', Oxford Review of Economic Policy, 34(1-2). 